\title{
Porównanie europejskich skal ekologicznych liczb wskaźnikowych w ocenie środowiska fizycznogeograficznego na podstawie charakterystycznych gatunków roślin wrzosowisk i ubogich muraw bliźniczkowych z klasy Nardo-Callunetea
}

\section{A comparison of European scales of ecological indicator values in assessing the natural environment on the basis of species characteristic for heaths and poor grasslands of class Nardo-Callunetea}

\author{
Ewa Roo-Zielińska \\ Instytut Geografii i Przestrzennego Zagospodarowania im. Stanisława Leszczyckiego PAN \\ ul. Twarda 51/55, 00-818 Warszawa \\ e.roo@twarda.pan.pl
}

\begin{abstract}
Zarys treści. Podstawowym przedmiotem opracowania jest porównanie trzech oryginalnych skal ekologicznych liczb wskaźnikowych powstałych w różnych regionach geograficznych Europy Środkowej: (1) w Niemczech - H. Ellenberga i innych (1991), (2) w Szwajcarii - E. Landolta (1977) i (3) w Polsce - K. Zarzyckiego i innych (2002). Do porównania wykorzystano zbiór gatunków roślin naczyniowych charakterystycznych dla wrzosowisk i ubogich muraw bliźniczkowych z klasy Nardo-Callunetea. Celem analizy jest odpowiedź na pytanie, w jakim stopniu skale liczb ekologicznych, wywodzące się z różnych części Europy Środkowej, są zgodne w wymaganiach ekologicznych tych samych gatunków wyrażonych przez trzy liczby wskaźnikowe dla każdej z sześciu cech środowiska geograficznego: klimatycznych - światła, temperatury i stopnia kontynentalizmu oraz glebowych - wilgotności, kwasowości i zawartości azotu. Najbardziej zgodne okazały się skale Ellenberga i Landolta. Dotyczy to podobnego waloru wskaźnikowego gatunków roślin względem warunków termicznych, wilgotności gleby i jej kwasowości, a także zawartości azotu w podłożu. Zgodność skal Landolta i Zarzyckiego dotyczy diagnozy ekologicznej względem warunków świetInych, stopnia kontynentalizmu i wilgotności gleby. Skale Ellenberga i Zarzyckiego określiły podobnie walor wskaźnikowy gatunków względem warunków świetlnych, warunków termicznych i wilgotności gleby. Walor wskaźnikowy analizowanych gatunków względem kwasowości gleby różni się wyraźnie w ocenie ekologicznej Landolta i Zarzyckiego, dotyczy to także stopnia kontynentalizmu.
\end{abstract}

Słowa kluczowe: skale ekologicznych liczb wskaźnikowych, wrzosowiska, ubogie murawy bliźniczkowe, charakterystyczne gatunki roślin, środowisko fizycznogeograficzne. 


\section{Wstęp}

Gatunki roślin wyróżniają się specyficzną właściwością tzw. nadinformatywnością ${ }^{1}$, pozwalającą na określenie tych komponentów środowiska przyrodniczego, z którymi są ekologicznie związane. Założenie to, leży u podstaw fitoindykacji geobotanicznej (gr. fito - roślina, łac. indicare - wskazać). Każdy gatunek roślin ma bowiem właściwy sobie ustrój ekologiczny (m.in. formę życiową, sposób rozprzestrzeniania) czyli zespół właściwości i cech, które kształtują jego wymagania ekologiczne i pozwalają mu na zajmowanie określonego środowiska (Motyka, 1962; Kershaw, 1978; Remmert, 1985; Podbielkowski, 1991; Falińska, 1997). Optymalny wzrost i rozwój roślin możliwy jest jedynie w odpowiednich dla danego gatunku warunkach środowiska fizycznogeograficznego. Poznanie tych wymagań stało się podstawą opracowań znanych jako ekologiczne liczby wskaźnikowe, w których stopień adaptacji gatunku do poszczególnych czynników abiotycznych środowiska został przedstawiony w skali liczbowej (Ellenberg i inni, 1991; Kozłowska, 1991; Lindacher, 1995; Zarzycki i inni, 2002; Roo-Zielińska, 2014). Ekologiczne liczby wskaźnikowe znajdują zastosowanie w ocenie środowiska fizycznogeograficznego na podstawie bytujących w nim gatunków roślin

Przyjęto za W. Matuszkiewiczem (2001) założenie, że gatunek charakterystyczny dla danej jednostki fitosocjologicznej (syntaksonu) ${ }^{2}$ jest to gatunek, który na pewnym terytorium ma punkt ciężkości występowania w danym syntaksonie - w porównaniu z wszystkimi innymi równorzędnymi syntaksonami. Pozwala to traktować jednostki fitosocjologiczne z właściwym im zestawem gatunków charakterystycznych, jako wzorcowe (reperowe) wskaźniki warunków środowiska fizycznogeograficznego. Koncepcja gatunków charakterystycznych wynika z różnic w zakresie tolerancji ekologicznej gatunków roślin. Jest to bowiem jednocześnie kategoria gatunków diagnostycznych, które mogą być subtelnymi wskaźnikami warunków ekologicznych zbiorowiska roślinnego. Warto również podkreślić, że grupy ekologiczne gatunków, związane z siedliskami skrajnymi pod jakimś względem (np. gatunki kalcyfilne, acydofilne, hydrofilne, nitrofilne) pokrywają się w dużej mierze z grupami gatunków charakterystycznych i wyróżniających jednostek fitosocjologicznych, które mają swoją wyraźną charakterystykę ekologiczną (Matuszkiewicz, 2001).

Porównania trzech systemów liczb ekologicznych podjęto się z kilku powodów: (1) pochodzą one z Europy Środkowej, choć z różnych regionów, (2) charakteryzują te same czynniki środowiska przyrodniczego (klimatyczne i glebowe), (3) autorzy stosują skale ekologiczne, których podstawą jest zbliżona idea, (4) w literaturze

\footnotetext{
${ }^{1}$ Nadinformatywność - zdolność wskaźnikowa flory i roślinności nie tylko własnego stanu (autoindykacja), ale wraz z zestawem cech diagnostycznych, stanu i procesów zachodzących w tych składowych środowiska, które są dla nich ekologicznie istotne (Kostrowicki i Wójcik, 1972).

2 Jednostka syntaksonomiczna (syntakson) - jednostka systematyczna bez względu na rangę w hierarchicznie ujętym florystyczno-fitosocjologicznym systemie zbiorowisk roślinnych według zasad J. Brauna-Blanqueta (Matuszkiewicz, 2001).
} 
przedmiotu brakuje tego typu całościowych analiz porównawczych, a te, które istnieją dotyczą najwyżej dwóch systemów - przeważnie Ellenberga i Zarzyckiego (Kozłowska, 1991; Dzwonko i Loster, 2000).

W prezentowanym opracowaniu przedmiotem analizy porównawczej są trzy europejskie skale ekologicznych liczb wskaźnikowych powstałe w różnych regionach geograficznych środkowej Europy a mianowicie w Niemczech - H. Ellenberga i innych (1991), w Szwajcarii - E. Landolta (1977) i w Polsce - K. Zarzyckiego i innych (2002). Skale te cechuje zbliżona koncepcja oceny wymagań gatunków roślin naczyniowych względem tych samych sześciu czynników środowiska fizycznogeograficznego: klimatycznych: (światła - L, temperatury - T, stopnia kontynentalizmu - K) i glebowych (wilgotności - F, kwasowości - R oraz zawartości azotu - N) (ryc. 1).

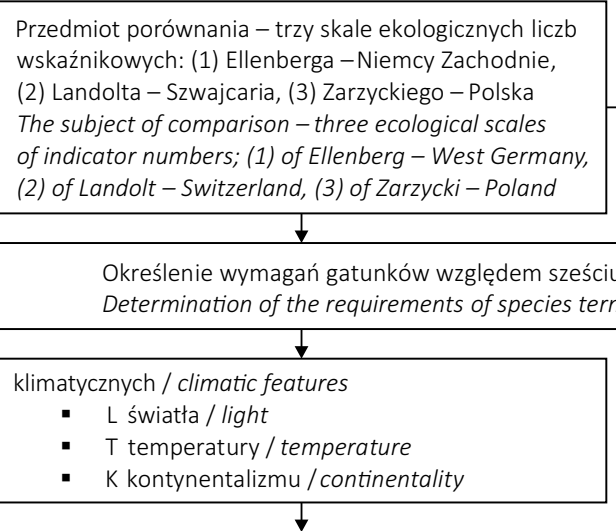

Narzędzie porównania - lista charakterystycznych gatunków roślin wrzosowisk i ubogich muraw bliźniczkowych z klasy Nardo-Callunetea

Comparison tool - the set of characteristic plant species of heaths and poor grasslands from Nardo-Callunetea class

Porównanie trzech oryginalnych skal w diagnozie gatunków roślin wrzosowisk i ubogich muraw bliźniczkowych jako wskaźników warunków środowiska fizycznogeograficznego

Comparison of the three original ecological scales in diagnosis of plant species of heaths and poor grasslands as indicators of environmental conditions

Ryc. 1. Skale ekologicznych liczb wskaźnikowych jako przedmiot analizy porównawczej i wykorzystane $w$ tym celu elementy

Scales of ecological indicator values as a subject of comparative analysis and elements used for this purpose

Opracowanie własne, podobnie pozostałe tabele i ryciny / Autohr's own elaboration, like remaining tables and figures

Do analiz wykorzystano wykaz gatunków roślin naczyniowych charakterystycznych dla wrzosowisk i ubogich muraw bliźniczkowych z klasy Nardo-Callunetea zawarty w Przewodniku do oznaczania zbiorowisk roślinnych W. Matuszkiewicza (2001). Opis florystyczno-ekologiczny tych zbiorowisk znaleźć można również w innych opracowaniach (Wysocki i Sikorski, 2009; Roo-Zielińska, 2014). Klasa Nardo-Callunetea obejmuje półnaturalne i antropogeniczne zbiorowiska, które w pierwotnym krajobrazie zajmowały niewielkie powierzchnie w szczególnych warunkach środowiska, natomiast wskutek działalności człowieka rozprzestrzeniły się 
spontanicznie i wykształciły w obecnej postaci. Są to: (1) acydofilne niskie murawy z panującą bliźniczką psią trawką (Nardus stricta) - rząd Nardetalia oraz (2) zbiorowiska krzewinkowe z panującym wrzosem (Calluna vulgaris) - rząd Calluno-Ulicetalia. Murawy bliźniczkowe występują na bardzo ubogim i kwaśnym podłożu, zaś wrzosowiska na ubogich i kwaśnych glebach bielicowych (Matuszkiewicz, 2001).

Spektra ekologiczne związków zespołów roślinnych klasy Nardo-Callunetea wyrażone wartościami wskaźników ekologicznych, przedstawiono w opracowaniu Wskaźniki ekologiczne zespołów roślinnych Polski (Roo-Zielińska, 2014). Zastosowano w nim jedną oryginalną skalę ekologicznych liczb wskaźnikowych Ellenberga (Ellenberg i inni, 1991; Lindacher, 1995) i na jej podstawie wykazano, że klasa Nardo-Callunetea jest indykatorem stanowisk umiarkowanie ( $L$ 6-7) i w pełni naświetlonych (L 8-9), gleb świeżych (F 4-5), kwaśnych (R 2-3) i o niskiej zawartości azotu (N 2-3). Choć amplituda ekologiczna tych zbiorowisk jest stosunkowo wąska to podobnie, jak w przypadku już przeanalizowanych zbiorowisk roślinnych należących do czterech klas fitosocjologicznych (Roo-Zielińska, 2004, 2009, 2012, 2015) należy oczekiwać, że autorzy omawianych trzech skal różnie ocenili rolę zbioru gatunków charakterystycznych jako indykatorów wybranych warunków ekologiczno-siedliskowych. Podstawowym celem tej analizy porównawczej jest zatem odpowiedź na pytanie, w jakim stopniu skale liczb ekologicznych wywodzące się z różnych części Europy Środkowej są zgodne (lub odmienne) w diagnozach ekologicznych (klimatycznych i glebowych) tych samych gatunków, a wyrażonych przez trzy liczby wskaźnikowe (odpowiadające trzem skalom) dla każdej z sześciu cech środowiska geograficznego.

Interpretacja wyników, oprócz wyjaśnienia przyczyn zgodności i różnic w diagnozach siedliskowych gatunków charakterystycznych tych zbiorowisk, polegała również na sformułowaniu prawidłowości wynikających ze zgodności i różnic skal na podstawie pięciu zbiorów gatunków charakterystycznych z klas: (1) Nardo-Callunetea (wrzosowiska i ubogie murawy bliźniczkowe), (2) Koelerio glaucae-Corynephoretea canescentis (murawy napiaskowe), (3) Festuco-Brometea (murawy ciepłolubne), (4) Molinio-Arrhenatheretea (łąki i pastwiska) oraz (5) Querco-Fagetea (lasy liściaste). Uwzględniono tylko gatunki roślin naczyniowych, gdyż istnieją dla nich pełne bazy danych dysponujące różnorodnymi diagnozami ekologicznymi. Dla pozostałych grup, takich jak mchy i porosty, opracowania są niekompletne.

\section{Metody analizy - ekologiczne skale liczb wskaźnikowych}

W opracowaniu wykorzystano bazę danych PHANART Database of Centraleuropean Vascular Plants (Lindacher, 1995), zawierającą ekologiczne skale gatunkowe H. Ellenberga i innych (1991) i E. Landolta (1977) oraz wykaz liczb wskaźnikowych K. Zarzyckiego (Zarzycki i inni, 2002). Szacunkowe diagnozy siedliskowe gatunków roślin wyrażone są liczbami wskaźnikowymi. Skale ekologicznych liczb wskaźniko- 
wych mogą być różne, zależnie od przyjętej arbitralnie przez autora rozpiętości (liczby stopni). Ellenberg i inni (1991) szacuje wymagania ekologiczno-siedliskowe gatunków w skali 9-stopniowej (dla wilgotności gleb [F] - 12-stopniowej), pozostali dwaj autorzy w skali 5-stopniowej (Landolt, 1977; Zarzycki i inni, 2002) wszystkie wyrażone są wzrostem natężenia danego czynnika.

Jak wspomniano, w opracowaniu K. Zarzyckiego i innych (2002) przyjęto 5stopniową skalę natężenia czynnika. Jednocześnie stan pośredni natężenia czynnika został wyrażony ułamkami (np. pięciornik srebrny (Potentilla argentea) przy zakresie kwasowości $R=3-4$ otrzymał wartość $R=3,5$ ). Skala Ellenberga stosuje liczbę 0 dla określenia szerokiej amplitudy ekologicznej gatunków, które nie mają wartości wskaźnikowej. E. Landolt (1977) dla zdecydowanej większości z nich podaje wartości przeciętne, a K. Zarzycki i inni (2002) wartości przeciętne lub szeroki zakres liczb wskaźnikowych. Pełny opis skal wymagań gatunków roślin - wskaźników warunków środowiska fizycznogeograficznego znajduje się w pracach E. Roo-Zielińskiej (2004, 2014) oraz E. Roo-Zielińskiej i innych (2007). Na potrzeby tego artykułu podano je w wersji zmodyfikowanej, po sprowadzeniu ich do wspólnej 5-stopniowej skali (tab. 1 i 2).

Tabela 1. Sposób sprowadzenia dwóch skal - Ellenberga i Zarzyckiego do jednej wspólnej - jak w systemie Landolta - pięciostopniowej skali

Means of modifying the Ellenberg and Zarzycki scales to a common 5-degree scale, as in the Landolt system

\begin{tabular}{|c|c|c|c|}
\hline $\begin{array}{c}\text { Skala Landolta } \\
\text { Landolt scale }\end{array}$ & \multicolumn{2}{|c|}{$\begin{array}{c}\text { Skala Ellenberga } \\
\text { Ellenberg scale }\end{array}$} & $\begin{array}{c}\text { Skala Zarzyckiego } \\
\text { Zarzycki scale }\end{array}$ \\
\hline LT K F R N & L T F R N & K & L T K F R N \\
\hline 1 & 1 & $1-2$ & 1 \\
2 & $2-3$ & $3-4$ & $1,5-2$ \\
3 & $4-5$ & 5 & $2,5-3$ \\
4 & $6-7$ & $6-7$ & $3,5-4$ \\
5 & $8-9$ & $8-9$ & $4,5-5$ \\
\hline
\end{tabular}

Cechy środowiska fizycznogeograficznego/Features of the geographical environment gdzie: $\mathrm{L}$ - światło, $\mathrm{T}$ - temperatura, $\mathrm{K}$ - kontynentalizm, $\mathrm{F}$ - wilgotność gleb, $\mathrm{R}$ - kwasowość gleb, $\mathrm{N}$ - zawartość azotu w glebie

$L$ - light, $T$-temperature, $K$ - continentality, $F$ - soil moisture, $R$ - soil acidity, $N$ - soil nitrogen Źródło/Source: Roo-Zielińska (2009).

W kolejnych etapach analizy każda z sześciu cech środowiska przyrodniczego została porównana w następujących kombinacjach systemów: Ellenberga i Landolta, Ellenberga i Zarzyckiego, Landolta i Zarzyckiego. W analizie nie uwzględniono gatunków o szerokiej amplitudzie ekologicznej oraz tych, dla których brakowało informacji. Zostały one usunięte także z systemu porównywanego, toteż w „parach" systemów porównywana była ta sama liczba gatunków (choć mogła być różna między parami systemów oraz poszczególnymi cechami) (ryc. 2, tab. 3). 
Tabela 2. Zmodyfikowane skale wymagań gatunków roślin - wskaźników sześciu cech środowiska przyrodniczego

Modified scales for the ecological requirements of plant species as indicators of six features of the natural environment

\begin{tabular}{|c|c|c|c|c|c|c|}
\hline \multirow{3}{*}{$\begin{array}{c}\text { Rozpiętość } \\
\text { skal } \\
\text { Range } \\
\text { of scales }\end{array}$} & \multicolumn{6}{|c|}{$\begin{array}{l}\text { Gatunki - wskaźniki } \\
\text { Species as indicators }\end{array}$} \\
\hline & L & $\mathrm{T}$ & $\mathrm{K}$ & $\mathrm{F}$ & $\mathrm{R}$ & $\mathrm{N}$ \\
\hline & $\begin{array}{l}\text { Stanowiska } \\
\text { Sites }\end{array}$ & \multicolumn{2}{|c|}{$\begin{array}{l}\text { Obszary } \\
\text { Regions }\end{array}$} & \multicolumn{3}{|c|}{$\begin{array}{l}\text { Gleby } \\
\text { Soils }\end{array}$} \\
\hline 1 & $\begin{array}{l}\text { głębokiego cienia } \\
\text { deep shade }\end{array}$ & $\begin{array}{l}\text { najzimniejsze } \\
\text { coldest }\end{array}$ & $\begin{array}{l}\text { oceaniczne } \\
\text { atlantic }\end{array}$ & $\begin{array}{l}\text { skrajnie suche } \\
\text { extremely dry }\end{array}$ & $\begin{array}{l}\text { silnie kwaśne } \\
\text { highly acidic }\end{array}$ & $\begin{array}{l}\text { skrajnie ubogie } \\
\text { extremely poor }\end{array}$ \\
\hline 2 & $\begin{array}{l}\text { cienia } \\
\text { moderate shade }\end{array}$ & $\begin{array}{l}\text { zimne } \\
\text { moderately cold }\end{array}$ & $\begin{array}{l}\text { suboceaniczne } \\
\text { subatlantic }\end{array}$ & $\begin{array}{l}\text { suche } \\
\text { dry }\end{array}$ & $\begin{array}{l}\text { kwaśne } \\
\text { acidic }\end{array}$ & $\begin{array}{l}\text { ubogie } \\
\text { poor }\end{array}$ \\
\hline 3 & $\begin{array}{l}\text { półcienia } \\
\text { semi-shade }\end{array}$ & $\begin{array}{l}\text { umiarkowanie } \\
\text { chtodne } \\
\text { moderately cool }\end{array}$ & $\begin{array}{l}\text { przejściowe } \\
\text { no continentality } \\
\text { preference }\end{array}$ & $\begin{array}{l}\text { świeże } \\
\text { mesic }\end{array}$ & $\begin{array}{l}\text { umiarkowanie } \\
\text { kwaśne } \\
\text { moderately acidic }\end{array}$ & $\begin{array}{l}\text { umiarkowanie } \\
\text { zasobne } \\
\text { moderately poor }\end{array}$ \\
\hline 4 & $\begin{array}{l}\text { naświetlone } \\
\text { moderate light }\end{array}$ & $\begin{array}{l}\text { umiarkowanie ciepłe } \\
\text { moderately warm }\end{array}$ & $\begin{array}{l}\text { subkontynentalne } \\
\text { subcontinental }\end{array}$ & $\begin{array}{l}\text { wilgotne } \\
\text { moist }\end{array}$ & $\begin{array}{l}\text { słabo kwaśne i słabo } \\
\text { zasadowe } \\
\text { neutral }\end{array}$ & $\begin{array}{l}\text { zasobne } \\
\text { rich }\end{array}$ \\
\hline 5 & $\begin{array}{l}\text { w pełni naświetlone } \\
\text { full light }\end{array}$ & $\begin{array}{l}\text { najcieplejsze } \\
\text { warmest }\end{array}$ & $\begin{array}{l}\text { kontynentalne } \\
\text { continental }\end{array}$ & $\begin{array}{l}\text { mokre } \\
\text { wet }\end{array}$ & $\begin{array}{l}\text { zasadowe } \\
\text { alkaline }\end{array}$ & $\begin{array}{l}\text { bardzo zasobne } \\
\text { very rich }\end{array}$ \\
\hline
\end{tabular}


Tabela 3. Liczba gatunków oraz amplituda ekologiczna zbioru charakterystycznych gatunków wrzosowisk i ubogich muraw bliźniczkowych z klasy Nardo-Callunetea w parach porównywanych, zmodyfikowanych skal liczb wskaźnikowych

The number and ecological spectra of characteristic species of heaths and poor grasslands of class Nardo-Callunetea in compared pairs of modified indicator scales

\begin{tabular}{|c|c|c|c|c|c|c|c|c|c|c|c|c|}
\hline \multirow{3}{*}{$\begin{array}{l}\text { Pary skal } \\
\text { Pairs } \\
\text { of scales }\end{array}$} & \multicolumn{12}{|c|}{$\begin{array}{l}\text { Cechy środowiska fizycznogeograficznego } \\
\text { Features of the geographical environment }\end{array}$} \\
\hline & \multicolumn{2}{|c|}{$\mathrm{L}$} & \multicolumn{2}{|c|}{$\mathrm{T}$} & \multicolumn{2}{|c|}{$\mathrm{K}$} & \multicolumn{2}{|c|}{$F$} & \multicolumn{2}{|c|}{$\mathrm{R}$} & \multicolumn{2}{|c|}{$\mathrm{N}$} \\
\hline & $\begin{array}{c}\text { Liczba gat. } \\
\text { Species } \\
\text { number }\end{array}$ & Min-max & $\begin{array}{l}\text { Liczba gat. } \\
\text { Species } \\
\text { number }\end{array}$ & Min-max & $\begin{array}{c}\text { Liczba gat. } \\
\text { Species } \\
\text { number }\end{array}$ & Min-max & $\begin{array}{c}\text { Liczba gat. } \\
\text { Species } \\
\text { number }\end{array}$ & Min-max & $\begin{array}{c}\text { Liczba gat. } \\
\text { Species } \\
\text { number }\end{array}$ & Min-max & $\begin{array}{c}\text { Liczba gat. } \\
\text { Species } \\
\text { number }\end{array}$ & Min-max \\
\hline $\begin{array}{l}\text { Ellenberg } \\
\text { Landolt }\end{array}$ & 51 & $\begin{array}{l}3-5 \\
2-4\end{array}$ & 28 & $\begin{array}{l}2-4 \\
2-5\end{array}$ & 49 & $\begin{array}{l}2-4 \\
1-5\end{array}$ & 46 & $\begin{array}{l}2-5 \\
1-5\end{array}$ & 45 & $\begin{array}{l}1-5 \\
1-4\end{array}$ & 53 & $\begin{array}{l}1-3 \\
1-3\end{array}$ \\
\hline $\begin{array}{l}\text { Ellenberg } \\
\text { Zarzycki }\end{array}$ & 52 & $\begin{array}{l}3-5 \\
3-5\end{array}$ & 28 & $\begin{array}{l}2-4 \\
2-5\end{array}$ & 49 & $\begin{array}{l}2-4 \\
2-4\end{array}$ & 46 & $\begin{array}{l}2-5 \\
2-5\end{array}$ & 44 & $\begin{array}{l}1-5 \\
2-5\end{array}$ & 53 & $\begin{array}{l}1-3 \\
2-4\end{array}$ \\
\hline $\begin{array}{l}\text { Landolt } \\
\text { Zarzycki }\end{array}$ & 38 & $\begin{array}{l}2-4 \\
3-5\end{array}$ & 50 & $\begin{array}{l}1-5 \\
2-5\end{array}$ & 53 & $\begin{array}{l}1-5 \\
2-4\end{array}$ & 53 & $\begin{array}{l}1-5 \\
2-5\end{array}$ & 51 & $\begin{array}{l}1-4 \\
2-5\end{array}$ & 53 & $\begin{array}{l}1-3 \\
2-4\end{array}$ \\
\hline
\end{tabular}

gdzie: $\mathrm{L}$ - światło, $\mathrm{T}$ - temperatura, $\mathrm{K}$ - kontynentalizm, $\mathrm{F}$ - wilgotność gleb, $\mathrm{R}$ - kwasowość gleb, $\mathrm{N}$ - zawartość azotu w glebie $L$ - light, $T$-temperature, $K$ - continentality, $F$ - soil moisture, $R$ - soil acidity, $N$ - soil nitrogen 


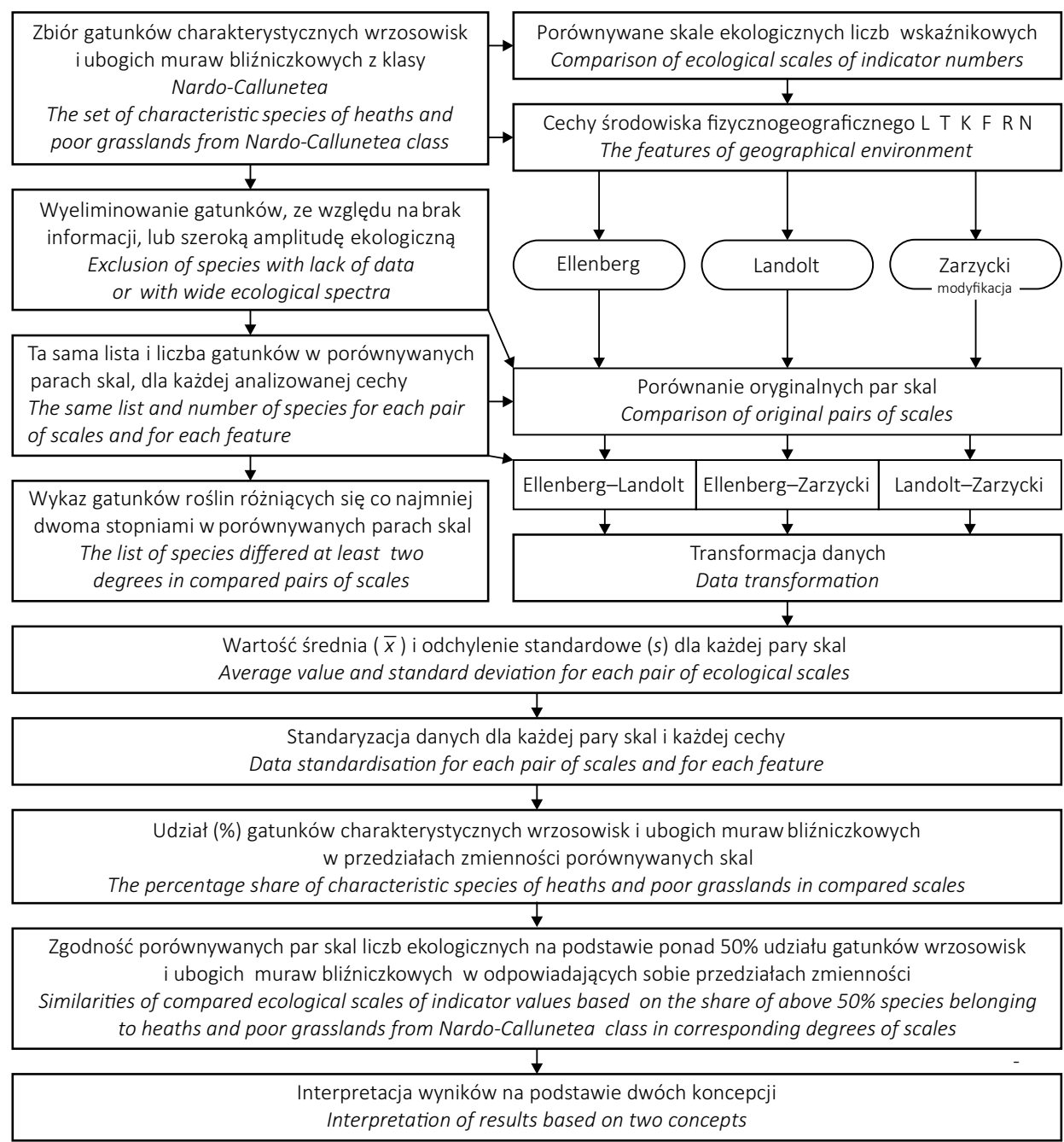

Ryc. 2. Schemat porównania trzech skal ekologicznych liczb wskaźnikowych: Ellenberga, Landolta i Zarzyckiego na podstawie zbioru charakterystycznych gatunków wrzosowisk i ubogich muraw bliżniczkowych z klasy Nardo-Callunetea dla każdej z sześciu cech środowiska fizycznogeograficznego: światła (L), temperatury (T), stopnia kontynentalizmu (K), wilgotności gleb (F), ich kwasowości (R) oraz zawartości azotu (N) Comparative analysis in relation to the ecological scales of indicator values on the basis of species characteristic for heaths and poor grasslands of class Nardo-Callunetea (proposed by Ellenberg, Landolt, Zarzycki) with relation to six environmental features: light intensity [L], temperature [T] continentality [K], soil moisture [F], acidity [R] and nitrogen content [N] 
Porównanie trzech oryginalnych skal o różnej rozpiętości było możliwe po sprowadzeniu liczb wskaźnikowych do pewnego wspólnego „mianownika” (tab. 1). W tym celu dla każdej porównywanej pary systemów zastosowano następujące kroki (ryc. 2):

1) obliczono wartości średnie ekologicznych liczb wskaźnikowych $(\bar{x})$ i odchylenie standardowe (s);

2) przeprowadzono standaryzację liczb wskaźnikowych według wzoru $u=(x-\bar{x}) / s$

3) dla każdego gatunku obliczono różnice wartości cech standaryzowanych, które następnie zamieniono na wartości bezwzględne;

4) cały zbiór uporządkowano według wzrastającej wartości bezwzględnej różnicy cech.

W ten sposób otrzymano zbiór o powtarzających się wartościach bezwzględnych różnic standaryzowanych cech (liczb wskaźnikowych), co pozwoliło na porównanie każdej pary systemów ekologicznych w stosunku do sześciu cech środowiska przyrodniczego. Przyjęto, że pary liczb wskaźnikowych porównywanych systemów są zgodne wówczas, gdy udział zbioru gatunków w odpowiadających sobie stopniach skal jest równy, lub przekracza 50\% (ryc. 2). Dla każdej analizowanej cechy środowiska przyrodniczego i każdej pary porównywanych systemów podano liczbę gatunków oraz zakresy ich wymagań według zmodyfikowanych pięciostopniowych skal liczb wskaźnikowych i według nich przeprowadzono interpretację uzyskanych wyników (tab. 3).

\section{Analiza porównawcza skal ekologicznych liczb wskaźnikowych na podstawie udziału charakterystycznych gatunków wrzosowisk i ubogich muraw bliźniczkowych z klasy Nardo-Callunetea w przedziałach zmienności porównywanych skal}

Porównanie skali wymagań gatunków roślin - wskaźników intensywności światła [L]

Udziały procentowe w przedziałach zmienności porównywanych trzech skal wskazują, że amplituda gatunków charakterystycznych wrzosowisk i ubogich muraw bliźniczkowych - wskaźników intensywności światła (L) waha się od L 3 do L 5 tzn. od stanowisk umiarkowanie cienistych do w pełni naświetlonych. Według skal Landolta i Zarzyckiego zdecydowana większość tych gatunków to wskaźniki stanowisk umiarkowanie naświetlonych (L_L i L_Z 4 - ponad 70\%), natomiast według skali Ellenberga ok. 50\% to wskaźniki miejsc umiarkowanie naświetlonych (L_E 4) i aż ok. 45\% pełnego światła (L_E 5). Według diagnoz ekologicznych trzech autorów brak jest gatunków wskazujących na siedliska głęboko cieniste ( $L$ 1) i cieniste (L 2), co jest zgodne ze specyfiką zbiorowisk należących do tej klasy (tab. 4). 
Tabela 4. Udział (\%) gatunków charakterystycznych wrzosowisk i ubogich muraw bliźniczkowych z klasy Nardo-Callunetea - wskaźników intensywności światła [L] w przedziałach zmienności porównywanych skal

Percentage shares of characteristic species of heaths and poor grasslands with Nardus stricta from class Nardo-Callunetea, as indicators of light intensity [L] in the compared scales

\begin{tabular}{|c|c|c|c|c|}
\hline \multirow{2}{*}{$\begin{array}{c}\text { Stanowiska } \\
\text { Sites of }\end{array}$} & \multirow{2}{*}{$\begin{array}{l}\text { Skala zmodyfikowana } \\
\text { Modified scale }\end{array}$} & L_E & $L_{-} \mathrm{L}$ & L_Z \\
\hline & & \multicolumn{3}{|c|}{ \% gatunków/Species (\%) } \\
\hline $\begin{array}{l}\text { Głębokiego cienia } \\
\text { Deep shade }\end{array}$ & 1 & 0,0 & 0,0 & 0,0 \\
\hline $\begin{array}{l}\text { Cienia } \\
\text { Moderate shade }\end{array}$ & 2 & 0,0 & 0,0 & 0,0 \\
\hline $\begin{array}{l}\text { Umiarkowanego cienia } \\
\text { Semi-shade }\end{array}$ & 3 & 5,9 & 26,0 & 7,6 \\
\hline $\begin{array}{l}\text { Umiarkowanego światła } \\
\text { Moderate light }\end{array}$ & 4 & 49,5 & 74,1 & 72,4 \\
\hline $\begin{array}{l}\text { Pełnego światła } \\
\text { Full light }\end{array}$ & 5 & 44,7 & 0,0 & 20,0 \\
\hline
\end{tabular}

Skale światła $L$ / Light scales $L$

gdzie: L_E - skala Ellenberga, L_L - skala Landolta, L_Z - skala Zarzyckiego

$L_{-} E-$ the Ellenberg's scale, $L_{-} L_{-}-$the Landolt's scale, $L_{-} Z-$ the Zarzycki's scale

\section{Porównanie skal wymagań gatunków roślin - wskaźników warunków termicznych [T]}

Według skali Landolta amplituda gatunków - wskaźników warunków termicznych jest najszersza i obejmuje pełny jej zakres (T_L1 - T_L 5) czyli od obszarów najzimniejszych do najcieplejszych. Wskaźnikiem obszarów najzimniejszych w przypadku tej skali jest turzyca zawsze zielona (Carex sempervirens ssp. Tatrorum), (T_L 1). Według skali Zarzyckiego największą grupę tworzą gatunki - wskaźniki obszarów umiarkowanie ciepłych (T 4 - ok. 51\%), natomiast Ellenberg duża grupę gatunków określa jako indykatory obszarów umiarkowanie chłodnych (T_E 3 - ok. 46\%). Według skali Landolta nie można wyróżnić jednej dominującej grupy wskaźników, choć przeważają wskaźniki obszarów zimnych (T_L 2) i umiarkowanie chłodnych (T_L 3) - w obu przypadkach ok. 35\%. Według diagnoz ekologicznych dwóch autorów Ellenberga i Zarzyckiego brak jest gatunków wskazujących na obszary najzimniejsze (T_L1) (tab. 5).

\section{Porównanie skali wymagań gatunków roślin - wskaźników kontynentalizmu klimatu [K]}

Gatunki charakterystyczne budujące wrzosowiska i murawy bliźniczkowe według trzech autorskich skal różnią się walorem wskaźnikowym stopnia kontynentalizmu klimatu (K) (tab. 6). Ellenberg większości gatunkom przypisuje walor wskaźnikowy 
Tabela 5. Udział (\%) gatunków charakterystycznych wrzosowisk i ubogich muraw bliźniczkowych z klasy Nardo-Callunetea - wskaźników warunków termicznych [T] w przedziałach zmienności porównywanych skal

Percentage shares of characteristic species of heaths and poor grasslands with Nardus stricta from class Nardo-Callunetea, as indicators of temperature [T] in the compared scales

\begin{tabular}{|c|c|c|c|c|}
\hline \multirow{2}{*}{$\begin{array}{l}\text { Obszary } \\
\text { Regions }\end{array}$} & \multirow{2}{*}{$\begin{array}{l}\text { Skala zmodyfikowana } \\
\text { Modified scale }\end{array}$} & T_E & T_L & T_Z \\
\hline & & \multicolumn{3}{|c|}{ \% gatunków/Species (\%) } \\
\hline $\begin{array}{l}\text { Najzimniejsze } \\
\text { Coldest }\end{array}$ & 1 & 0,0 & 1,0 & 0,0 \\
\hline $\begin{array}{l}\text { Zimne } \\
\text { Moderately cold }\end{array}$ & 2 & 21,4 & 35,7 & 12,2 \\
\hline $\begin{array}{l}\text { Umiarkowanie chłodne } \\
\text { Moderately cool }\end{array}$ & 3 & 46,4 & 35,3 & 28,3 \\
\hline $\begin{array}{l}\text { Umiarkowanie ciepłe } \\
\text { Moderately warm }\end{array}$ & 4 & 32,1 & 24,3 & 51,2 \\
\hline $\begin{array}{l}\text { Najcieplejsze } \\
\text { Warmest }\end{array}$ & 5 & 0,0 & 3,8 & 8,4 \\
\hline
\end{tabular}

Skale temperatury $\mathrm{T}$ / Temperature scales $T$

gdzie: T_E - skala Ellenberga, T_L - skala Landolta, T_Z - skala Zarzyckiego

$T_{-} E$ - the Ellenberg's scale, $T_{-} L-$ the Landolt's scale, $T_{-} Z$ - the Zarzycki's scale

obszarów suboceanicznych (K_E 2 ok. 59\%) i towarzyszą im także wskaźniki obszarów oceanicznych (K_E1 - ok. 27\%). Landolt dużą grupę gatunków ocenia jako indykatory obszarów przejściowych (K_L 3 - ok. 46\%), towarzyszą im także gatunki - wskaźniki zarówno obszarów suboceanicznych (T_L 2 - ok. 30\%), jak i subkontynentalnych (K_L 4 - ok. 21\%). Na największy udział gatunków - indykatorów obszarów przejściowych wskazuje skala Zarzyckiego (K_Z 3 - ok. 77\%). Skala „K” Zarzyckiego nie wskazuje na obecność gatunków oceanicznych (K 1) oraz kontynenetalnych (K 5). Według Landolta w zbiorze gatunków charakterystycznych jest po jednym gatunku - wskaźniku obszarów oceanicznych (K_L 1) i kontynentalnych (K_L 5) (tab. 6). W pierwszym przypadku jest to gnidosz rozesłany (Pedicularis sylvatica), w drugim driakiew żółtawa (Scabiosa ochroleuca).

\section{Porównanie skali wymagań gatunków roślin - wskaźników wilgotności gleb [F]}

Według trzech porównywanych skal liczby F (wilgotności gleby) w omawianej grupie zbiorowisk dominują gatunki wskazujące na gleby świeże (F 3). Według skali Landolta wskaźnikom gleb świeżych (F_L 3 - ok. 51\%) towarzyszy znacząca grupa gatunków - indykatorów gleb suchych (F_L 2 - ok. 36\%). Według diagnozy ekologicznej Zarzyckiego dość licznie reprezentowane są wskaźniki gleb wilgotnych (F_Z 4 - ok. 25\%) (tab. 7). Według skali Landolta gorysz pagórkowy (Peucedanum oreoselinum) i driakiew żółtawa (Scabiosa ochroleuca) to gatunki skrajnie suchych gleb (F_L1). Gatunkiwskaźniki gleb mokrych (F 5) to wg Ellenberga gnidosz rozesłany (Pedicularis sy/vatica) oraz sit drobny (Juncus bulbosus), a wg Landolta i Zarzyckiego - tylko Juncus bulbosus. 
Tabela 6. Udział (\%) gatunków charakterystycznych wrzosowisk i ubogich muraw bliźniczkowych z klasy Nardo-Callunetea - wskaźników stopnia kontynentalizmu [K] w przedziałach zmienności porównywanych skal

Percentage shares of characteristic species of heaths and poor grasslands with Nardus stricta from class Nardo-Callunetea, as indicators of climate continentality $(K)$ in the compared scales

\begin{tabular}{|c|c|c|c|c|}
\hline \multirow{2}{*}{$\begin{array}{l}\text { Obszary } \\
\text { Regions }\end{array}$} & \multirow{2}{*}{$\begin{array}{l}\text { Skala zmodyfikowana } \\
\text { Modified scale }\end{array}$} & K_E & K_L & K_Z \\
\hline & & \multicolumn{3}{|c|}{ \% gatunków / Species (\%) } \\
\hline $\begin{array}{l}\text { Oceaniczne } \\
\text { Atlantic }\end{array}$ & 1 & 26,6 & 2,0 & 0,0 \\
\hline $\begin{array}{l}\text { Suboceaniczne } \\
\text { Subatlantic }\end{array}$ & 2 & 59,2 & 29,5 & 17,7 \\
\hline $\begin{array}{l}\text { Przejściowe } \\
\text { No continentality preference }\end{array}$ & 3 & 8,2 & 46,1 & 76,5 \\
\hline $\begin{array}{l}\text { Subkontynentalne } \\
\text { Subcontinental }\end{array}$ & 4 & 6,1 & 20,5 & 5,9 \\
\hline $\begin{array}{l}\text { Kontynentalne } \\
\text { Continental }\end{array}$ & 5 & 0,0 & 2,0 & 0,0 \\
\hline
\end{tabular}

Skale kontynentalizmu K / Continentality scales $K$

gdzie: K_E - skala Ellenberga, K_L - skala Landolta, K_Z - skala Zarzyckiego

$K \_E$ - the Ellenberg's scale, $K_{-} L-$ the Landolt's scale, $K \_Z$ - the Zarzycki's scale

Tabela 7. Udział (\%) gatunków charakterystycznych wrzosowisk i ubogich muraw bliźniczkowych z klasy Nardo-Callunetea - wskaźników wilgotności [F] w przedziałach zmienności porównywanych skal

Percentage shares of characteristic species of heaths and poor grasslands with Nardus stricta from class Nardo-Callunetea, as indicators of soil moisture (F) in the compared scales

\begin{tabular}{|c|c|c|c|c|}
\hline \multirow{2}{*}{$\begin{array}{l}\text { Gleby } \\
\text { Soils }\end{array}$} & \multirow{2}{*}{$\begin{array}{c}\text { Skala zmodyfikowana } \\
\text { Modified scale }\end{array}$} & F_E & $F_{-} L$ & W_Z \\
\hline & & \multicolumn{3}{|c|}{ \% gatunków / Species (\%) } \\
\hline $\begin{array}{l}\text { Skrajnie suche } \\
\text { Very dry }\end{array}$ & 1 & 0,0 & 4,1 & 0,0 \\
\hline $\begin{array}{l}\text { Suche } \\
\text { Dry }\end{array}$ & 2 & 8,8 & 36,4 & 17,2 \\
\hline $\begin{array}{l}\text { Świeże } \\
\text { Mesic }\end{array}$ & 3 & 71,7 & 51,4 & 55,5 \\
\hline $\begin{array}{l}\text { Wilgotne } \\
\text { Moist }\end{array}$ & 4 & 15,3 & 6,1 & 25,2 \\
\hline $\begin{array}{l}\text { Mokre } \\
\text { Wet }\end{array}$ & 5 & 4,3 & 2,1 & 2,1 \\
\hline
\end{tabular}

Skale wilgotności F / Moisture scales $F$

gdzie: F_E - skala Ellenberga, F_L - skala Landolta, W_Z - skala Zarzyckiego

$F_{-} E-$ the Ellenberg's scale, $F_{-} L_{-}-$the Landolt's scale, $\bar{W}_{-} Z-$ the Zarzycki's scale 
Porównanie skali wymagań gatunków roślin - wskaźników kwasowości gleb [R]

Zakres wymagań gatunków wrzosowisk i ubogich muraw bliźniczkowych - wskaźników kwasowości gleb według Ellenberga obejmuje pełny zakres skali-od wskaźników gleb silnie kwaśnych (R 1 ) do indykatorów gleb zasadowych (R 5). Według skali Landolta, zakres ten jest węższy o jeden stopień - od wskaźników gleb silnie kwaśnych (R 1) do gleb słabo kwaśnych i słabo zasadowych (R 4); natomiast według skali Zarzyckiego od gleb kwaśnych (R 2) do zasadowych (R 5). Według obu tych diagnoz ekologicznych w badanym zbiorze gatunków dominują wskaźniki gleb kwaśnych (R 2 - odpowiednio ok. 47\% i 53\%). Według skali Zarzyckiego dominującą grupę tworzą wskaźniki gleb umiarkowanie kwaśnych (R_Z 3 - ok. 50\%), przy czym warto podkreślić, że według tej samej skali, ok. 33\% to gatunki wskaźniki gleb słabo kwaśnych i słabo zasadowych (R_Z 4) (tab. 8). Zgodnie z diagnozą ekologiczną Ellenberga i Zarzyckiego pojedynczo występują wskaźniki gleb zasadowych (R 5) i są to odpowiednio driakiew żółtawa (Scabiosa ochroleuca) i turzyca wczesna (Carex praecox).

\section{Porównanie skal wymagań gatunków roślin - wskaźników zawartości azotu w glebach [N]}

Według skal Ellenberga i Landolta dominującą grupę gatunków (odpowiednio ok. 79\% i 76\%) tworzą gatunki - wskaźniki gleb ubogich w związki azotowe (N 2). Natomiast według polskiego autora ok. 60\% to gatunki - wskaźniki gleb umiarko-

Tabela 8. Udział (\%) gatunków charakterystycznych wrzosowisk i ubogich muraw bliźniczkowych z klasy Nardo-Callunetea - wskaźników kwasowości gleb [R] w przedziałach zmienności porównywanych skal

Percentage shares of characteristic species of heaths and poor grasslands with Nardus stricta from class Nardo-Callunetea, as indicators of soil acidity $[R]$ in the compared scales

\begin{tabular}{|c|c|c|c|c|}
\hline \multirow{2}{*}{$\begin{array}{l}\text { Gleby } \\
\text { Soils }\end{array}$} & \multirow{2}{*}{$\begin{array}{l}\text { Skala zmodyfikowana } \\
\text { Modified scale }\end{array}$} & R_E & R_L & R_Z \\
\hline & & \multicolumn{3}{|c|}{ \% gatunków / Species (\%) } \\
\hline $\begin{array}{l}\text { Silnie kwaśne } \\
\text { Highly acidic }\end{array}$ & 1 & 13,5 & 16,8 & 0,0 \\
\hline $\begin{array}{l}\text { Kwaśne } \\
\text { Acidic }\end{array}$ & 2 & 47,2 & 53,3 & 14,7 \\
\hline $\begin{array}{l}\text { Umiarkowanie kwaśne } \\
\text { Moderately acidic }\end{array}$ & 3 & 29,2 & 26,9 & 49,7 \\
\hline $\begin{array}{l}\text { Słabo kwaśne i słabo zasadowe } \\
\text { Neutral }\end{array}$ & 4 & 7,9 & 3,1 & 32,6 \\
\hline $\begin{array}{l}\text { Zasadowe } \\
\text { Alkaline }\end{array}$ & 5 & 2,3 & 0,0 & 3,1 \\
\hline
\end{tabular}

Skale kwasowosci R / Acidity scales $R$

gdzie: R_E - skala Ellenberga, R_L - skala Landolta, R_Z - skala Zarzyckiego

$R \_E$ - the Ellenberg's scale, $R \_L$ - the Landolt's scale, $R \_Z$ - the Zarzycki's scale 
wanie zasobnych (N_Z 3), przy czym znaczący udział mają indykatory gleb ubogich (N_Z 2 - ok. 30\%). Warto przy tym podkreślić, że amplituda wymagań gatunków według skali Zarzyckiego jest przesunięta, w porównaniu z pozostałymi, w kierunku gleb zasobnych (N_Z 4). Brak jest według tej skali gatunków wskaźników gleb skrajnie ubogich ( $N$ 1). W przypadku trzech analizowanych autorskich skal brak jest także wskaźników gleb bardzo zasobnych (N 5) (tab. 9).

Tabela 9. Udział (\%) gatunków charakterystycznych wrzosowisk i ubogich muraw bliźniczkowych z klasy Nardo-Callunetea - wskaźników zawartości azotu w glebach [N] w przedziałach zmienności porównywanych skal

Percentage shares of characteristic species of heaths and poor grasslands with Nardus stricta from class Nardo-Callunetea, as indicators of nitrogen content in the soil [N] in the compared scales

\begin{tabular}{|l|c|c|c|c|}
\hline \multicolumn{1}{|c|}{$\begin{array}{c}\text { Gleby } \\
\text { Soils }\end{array}$} & $\begin{array}{c}\text { Skala zmodyfikowana } \\
\text { Modified scale }\end{array}$ & N_E & N_L & Tr_Z \\
\cline { 3 - 5 } & 1 & 13,2 & 13,2 & 0,0 \\
\hline $\begin{array}{l}\text { Skrajnie ubogie } \\
\text { Extremely poor } \\
\text { Ubogie }\end{array}$ & 2 & 79,2 & 75,5 & 30,2 \\
$\begin{array}{l}\text { Poor } \\
\text { Umiarkowanie zasobne }\end{array}$ & 3 & 7,5 & 9,4 & 60,4 \\
$\begin{array}{l}\text { Moderately poor } \\
\text { Zasobne } \\
\text { Rich }\end{array}$ & 4 & 0,0 & 1,9 & 9,4 \\
$\begin{array}{l}\text { Bardzo zasobne } \\
\text { Very rich }\end{array}$ & 5 & 0,0 & 0,0 & 0,0 \\
\hline
\end{tabular}

Skale zawartości azotu $\mathrm{N} /$ Nitrogen scales $\mathrm{N}$

gdzie: N_E - skala Ellenberga, N_L - skala Landolta, Tr_Z - skala Zarzyckiego

$N_{-} E$ - the Ellenberg's scale, $N_{-} L-$ the Landolt's scale, $\bar{T} r_{-} Z-$ the Zarzycki's scale

\section{Zgodności i różnice trzech porównywanych skal w diagnozie siedliskowej gatunków wrzosowisk i ubogich muraw bliźniczkowych - wskaźników warunków środowiska fizycznogeograficznego}

Analiza porównawcza trzech systemów liczb ekologicznych zbioru gatunków charakterystycznych wrzosowisk i ubogich muraw bliźniczkowych (patrz tab. 3), pozwoliła wyróżnić 26 takich, których wymagania siedliskowe zostały zdecydowanie różnie określone odnośnie każdej z sześciu cech siedliskowych. Różnice te przedstawiono w zmodyfikowanych skalach 5-stopniowych i uwzględniono tylko gatunki różniące się co najmniej dwoma stopniami skali. Wyraźnie odmienne, co najmniej o dwa stopnie skali, diagnozy siedliskowe dotyczą różnej liczby gatunków, zależnie od analizowanego czynnika środowiska fizycznogeograficznego (tab. 10). 
Tabela 10. Wykaz gatunków roślin, których wymagania środowiskowe wyrażone liczbami wskaźnikowymi różnią się między trzema ekologicznymi systemami co najmniej dwoma stopniami skali

List of plant species whose ecological requirements defined by the three ecological indicator values differed by at least two degrees on the scale

\begin{tabular}{|c|c|c|c|c|c|c|c|c|c|c|c|c|c|c|c|c|c|c|c|c|c|c|c|c|c|c|c|c|c|c|c|c|}
\hline \multirow{3}{*}{ Lp. } & \multirow{3}{*}{$\begin{array}{l}\text { Nazwa gatunku } \\
\text { Name of species }\end{array}$} & \multicolumn{30}{|c|}{ Cechy środowiska geograficznego / Features of the geographical environment } & \multirow{3}{*}{$\begin{array}{l}\text { Skala } \\
\text { Scale }\end{array}$} \\
\hline & & \multicolumn{5}{|c|}{$\mathrm{L}$} & \multicolumn{5}{|c|}{$\mathrm{T}$} & \multicolumn{5}{|c|}{ K } & \multicolumn{5}{|c|}{$\mathrm{F}$} & \multicolumn{5}{|c|}{$\mathrm{R}$} & \multicolumn{5}{|c|}{$\mathrm{N}$} & \\
\hline & & 1 & 2 & 3 & 4 & 5 & 1 & 2 & 3 & 4 & 5 & 1 & 2 & 3 & 4 & 5 & 1 & 2 & 3 & 4 & 5 & 1 & 2 & 3 & 4 & 5 & 1 & 2 & 3 & 4 & 5 & \\
\hline 1 & $\begin{array}{l}\text { Calluna vulgaris } \\
\text { Wrzos zwyczajny }\end{array}$ & & & & & & & & & & & & & & & & & & & & & & & & & & & & & & & $\begin{array}{l}E \\
L \\
Z\end{array}$ \\
\hline 2 & $\begin{array}{l}\text { Hypericum maculatum } \\
\text { Dziurawiec czteroboczny }\end{array}$ & & & & & & & & & & & & & & & & & & & & & & & & & & & & & & & $\begin{array}{l}E \\
L \\
Z\end{array}$ \\
\hline 3 & $\begin{array}{l}\text { Lycopodium clavatum } \\
\text { Widłak goździsty }\end{array}$ & & & & & & & & & & & & & & & & & & & & & & & & & & & & & & & $\begin{array}{l}E \\
L \\
Z\end{array}$ \\
\hline 4 & $\begin{array}{l}\text { Veronica officinalis } \\
\text { Przetacznik leśny }\end{array}$ & & & & & & & & & & & & & & & & & & & & & & & & & & & & & & & $\begin{array}{l}E \\
L \\
Z\end{array}$ \\
\hline 5 & $\begin{array}{l}\text { Ajuga pyramidalis } \\
\text { Dąbrówka piramidalna }\end{array}$ & & & & & & & & & & & & & & & & & & & & & & & & & & & & & & & $\begin{array}{l}\mathrm{E} \\
\mathrm{L} \\
\mathrm{Z}\end{array}$ \\
\hline 6 & $\begin{array}{l}\text { Arctostaphylos uva-ursi } \\
\text { Mącznica lekarska }\end{array}$ & & & & & & & & & & & & & & & & & & & & & & & & & & & & & & & $\begin{array}{l}\mathrm{E} \\
\mathrm{L} \\
\mathrm{Z}\end{array}$ \\
\hline 7 & $\begin{array}{l}\text { Gentianella campestris } \\
\text { Goryczuszka (Goryczka) polna }\end{array}$ & & & & & & & & & & & & & & & & & & & & & & & & & & & & & & & $\begin{array}{l}\mathrm{E} \\
\mathrm{L} \\
\mathrm{Z}\end{array}$ \\
\hline 8 & $\begin{array}{l}\text { Juncus squarrosus } \\
\text { Sit sztywny }\end{array}$ & & & & & & & & & & & & & & & & & & & & & & & & & & & & & & & $\begin{array}{l}E \\
L \\
Z\end{array}$ \\
\hline
\end{tabular}




\begin{tabular}{|c|c|c|c|c|c|c|c|c|c|c|c|c|c|c|c|c|c|c|c|c|c|c|c|c|c|c|c|c|c|c|c|c|}
\hline \multirow{3}{*}{ Lp. } & \multirow{3}{*}{$\begin{array}{l}\text { Nazwa gatunku } \\
\text { Name of species }\end{array}$} & \multicolumn{30}{|c|}{ Cechy środowiska geograficznego / Features of the geographical environment } & \multirow{3}{*}{$\begin{array}{l}\text { Skala } \\
\text { Scale }\end{array}$} \\
\hline & & \multicolumn{5}{|c|}{$\mathrm{L}$} & \multicolumn{5}{|c|}{$\mathrm{T}$} & \multicolumn{5}{|c|}{$\mathrm{K}$} & \multicolumn{5}{|c|}{$\mathrm{F}$} & \multicolumn{5}{|c|}{$\mathrm{R}$} & \multicolumn{5}{|c|}{$\mathrm{N}$} & \\
\hline & & 1 & 2 & 3 & 4 & 5 & 1 & 2 & 3 & 4 & 5 & 1 & 2 & 3 & 4 & 5 & 1 & 2 & 3 & 4 & 5 & 1 & 2 & 3 & 4 & 5 & 1 & 2 & 3 & 4 & 5 & \\
\hline 9 & $\begin{array}{l}\text { Carex sempervirens ssp. tatrorum } \\
\text { Turzyca zawsze zielona }\end{array}$ & & & & & & & & & & & & & & & & & & & & & & & & & & & & & & & $\begin{array}{l}E \\
L \\
Z\end{array}$ \\
\hline 10 & $\begin{array}{l}\text { Galium pumilum var. glabrum } \\
\text { Przytulia szorstkoowockowa }\end{array}$ & & & & & & & & & & & & & & & & & & & & & & & & & & & & & & & $\begin{array}{l}E \\
L \\
Z\end{array}$ \\
\hline 11 & $\begin{array}{l}\text { Hieracium pilosella } \\
\text { Jastrzębiec kosmaczek }\end{array}$ & & & & & & & & & & & & & & & & & & & & & & & & & & & & & & & $\begin{array}{l}E \\
L \\
Z\end{array}$ \\
\hline 12 & $\begin{array}{l}\text { Polygala oxyptera } \\
\text { Krzyżownica ostroskrzydełkowa }\end{array}$ & & & & & & & & & & & & & & & & & & & & & & & & & & & & & & & $\begin{array}{l}E \\
L \\
Z\end{array}$ \\
\hline 13 & $\begin{array}{l}\text { Polygala vulgaris } \\
\text { Krzyżownica zwyczajna }\end{array}$ & & & & & & & & & & & & & & & & & & & & & & & & & & & & & & & $\begin{array}{l}E \\
L \\
Z\end{array}$ \\
\hline 14 & $\begin{array}{l}\text { Euphrasia nemorosa } \\
\text { Świetlik gajowy }\end{array}$ & & & & & & & & & & & & & & & & & & & & & & & & & & & & & & & $\begin{array}{l}E \\
L \\
Z\end{array}$ \\
\hline 15 & $\begin{array}{l}\text { Scabiosa ochroleuca } \\
\text { Driakiew żółtawa }\end{array}$ & & & & & & & & & & & & & & & & & & & & & & & & & & & & & & & $\begin{array}{l}E \\
L \\
Z\end{array}$ \\
\hline 16 & $\begin{array}{l}\text { Genista tinctoria } \\
\text { Janowiec barwierski }\end{array}$ & & & & & & & & & & & & & & & & & & & & & & & & & & & & & & & $\begin{array}{l}E \\
L \\
Z\end{array}$ \\
\hline 17 & $\begin{array}{l}\text { Agrostis capillaris (A. tenuius) } \\
\text { Mietlica pospolita }\end{array}$ & & & & & & & & & & & & & & & & & & & & & & & & & & & & & & & $\begin{array}{l}E \\
L \\
Z\end{array}$ \\
\hline
\end{tabular}




\begin{tabular}{|c|c|c|c|c|c|c|c|c|c|c|c|c|c|c|c|c|c|c|c|c|c|c|c|c|c|c|c|c|c|c|c|c|}
\hline \multirow{3}{*}{ Lp. } & \multirow{3}{*}{$\begin{array}{l}\text { Nazwa gatunku } \\
\text { Name of species }\end{array}$} & \multicolumn{30}{|c|}{ Cechy środowiska geograficznego / Features of the geographical environment } & \\
\hline & & \multicolumn{5}{|c|}{$\mathrm{L}$} & \multicolumn{5}{|c|}{\begin{tabular}{|c|} 
\\
\end{tabular}} & \multicolumn{5}{|c|}{$\mathrm{K}$} & \multicolumn{5}{|c|}{$\mathrm{F}$} & \multicolumn{5}{|c|}{$\mathrm{R}$} & \multicolumn{4}{|c|}{$\mathrm{N}$} & & \\
\hline & & 1 & 2 & 3 & 4 & 5 & 1 & 2 & 3 & 4 & 5 & 1 & 2 & 3 & 4 & 5 & 1 & 2 & 3 & 4 & 5 & 1 & 2 & 3 & 4 & 5 & 1 & 2 & 3 & 4 & 5 & \\
\hline 18 & $\begin{array}{l}\text { Coeloglossum viride } \\
\text { Ozorka zielona }\end{array}$ & & & & & & & & & & & & & & & & & & & & & & & & & & & & & & & $\begin{array}{l}E \\
L \\
Z\end{array}$ \\
\hline 19 & $\begin{array}{l}\text { Genista pilosa } \\
\text { Janowiec włosisty }\end{array}$ & & & & & & & & & & & & & & & & & & & & & & & & & & & & & & & $\begin{array}{l}E \\
L \\
Z\end{array}$ \\
\hline 20 & $\begin{array}{l}\text { Hieracium lactucella } \\
\text { Jastrzębiec gronkowy }\end{array}$ & & & & & & & & & & & & & & & & & & & & & & & & & & & & & & & $\begin{array}{l}\text { E } \\
L \\
Z\end{array}$ \\
\hline 21 & $\begin{array}{l}\text { Hieracium umbellatum } \\
\text { Jastrzębiec baldaszkowaty }\end{array}$ & & & & & & & & & & & & & & & & & & & & & & & & & & & & & & & $\begin{array}{l}E \\
L \\
Z\end{array}$ \\
\hline 22 & $\begin{array}{l}\text { Galium saxatile (G. harcynicum) } \\
\text { Przytulia hercyńska }\end{array}$ & & & & & & & & & & & & & & & & & & & & & & & & & & & & & & & $\begin{array}{l}E \\
L \\
Z\end{array}$ \\
\hline 23 & $\begin{array}{l}\text { Genista germanica } \\
\text { Janowiec ciernisty }\end{array}$ & & & & & & & & & & & & & & & & & & & & & & & & & & & & & & & $\begin{array}{l}E \\
L \\
Z\end{array}$ \\
\hline 24 & $\begin{array}{l}\text { Meum athamanticum } \\
\text { Wszewłoga górska }\end{array}$ & & & & & & & & & & & & & & & & & & & & & & & & & & & & & & & $\begin{array}{l}\mathrm{E} \\
\mathrm{L} \\
\mathrm{Z}\end{array}$ \\
\hline 25 & $\begin{array}{l}\text { Leucorchis albida } \\
\text { Gołek białawy }\end{array}$ & & & & & & & & & & & & & & & & & & & & & & & & & & & & & & & $\begin{array}{l}E \\
L \\
Z\end{array}$ \\
\hline
\end{tabular}


Tylko trzy gatunki wyraźnie różnią się walorem wskaźnikowym względem trzech cech środowiska fizycznogeograficznego. W przypadku dziurawca czterobocznego (Hypericum perforatum) i przetacznika leśnego (Veronica officinalis) są to różnie określone wymagania względem intensywności naświetlenia, kwasowości i zasobności gleb w związki azotowe (liczby L, R i N). Świetlik gajowy (Euphrasia nemorosa) różni się stopniem kontynentalizmu, a także kwasowości i zasobności siedlisk (liczby K, R i N) (tab. 10).

Interpretacja niezgodności diagnoz siedliskowych wykazanych 26 gatunków jest trudna i niejednoznaczna. Uzyskane różnice można tłumaczyć przesunięciem spektrum (optimum) ekologicznego gatunków w różnych częściach areału. Jest to hipoteza przyrodnicza wynikająca z odmienności flor lokalnych i innego układu konkurencyjnego, który może wpływać na tolerancję ekologiczną gatunków. Każdy gatunek ma w odniesieniu do poszczególnych czynników środowiskowych, (tj. dostęp do światła, temperatura powietrza, stopień kontynentalizmu, wilgotność podłoża, zasobność pokarmowa gleby i inne) określone granice, w obrębie których jest zdolny do życia. Granice te mogą się zmieniać pod wpływem innych czynników środowiskowych. Na przykład wyższe temperatury letnie mogą niejednokrotnie osłabiać ujemny wpływ temperatur zimowych. Fakty te są odbiciem ogólnej zasady, że na każdy organizm działa kompleks czynników środowiskowych wzajemnie się modyfikujących. Takie całościowe oddziaływanie środowiska ogromnie utrudnia analizę roli, jaka przypada w nim pojedynczym czynnikom (Strain i Bilings, 1974). Wśród tych 26 gatunków są podgatunki, a nie można wykluczyć, że także odmiany, które w Polsce, Niemczech czy Szwajcarii mogą mieć nieco inną amplitudę ekologiczną. Należy też pamiętać, że gatunki roślin mogą tworzyć różne ekotypy ${ }^{3}$, co także może być przyczyną odmiennych ocen ich waloru wskaźnikowego (tab. 10).

Mimo różnic $w$ diagnozach siedliskowych analizowanego zbioru gatunków charakterystycznych analiza porównawcza trzech systemów liczb wskaźnikowych wskazała na zgodność (ponad 50\% gatunków) porównywanych par skal w odniesieniu do analizowanych cech środowiska geograficznego (tab. 11). Zgodność systemów: (1) Ellenberga i Landolta dotyczy warunków termicznych (T), wilgotności gleb (F), ich kwasowości (R), a także zasobności siedlisk w mineralne związki azotowe (N); (2) Ellenberga i Zarzyckiego - intensywności naświetlenia (L), warunków termicznych (T) oraz wilgotności gleb (F); (3) Landolta i Zarzyckiego liczb - intensywności naświetlenia (L), stopnia kontynentalizmu (K) i wilgotności gleb (F). Warto podkreślić, że skale Landolta i Zarzyckiego osiągnęły tylko ok. 8\% zgodności w przypadku diagnozy ekologicznej gatunków roślin względem kwasowości gleb (R) (tab. 11). Niezgodności te wynikać mogą (1) z różnic klimatycznych i siedliskowych trzech regionów środkowej Europy, (2) z nieznacznie różnej listy gatunków charakterystycznych w analizowanych regionach (w Europie zachodniej może być brak gatunków charakterystycznych obecnych w Polsce).

${ }^{3}$ Ekotyp - populacja w obrębie gatunku przystosowana w wyniku ewolucji do specyficznych warunków środowiskowych (Falińska, 1997). 
Tabela 11. Zgodności i różnice porównywanych systemów ekologicznych liczb wskaźnikowych na podstawie ponad 50\% udziału gatunków wrzosowisk i ubogich muraw bliźniczkowych z klasy Nardo-Callunetea w odpowiadających sobie przedziałach zmienności skal Similarities and differences of compared ecological scales of indicator values based on the share of above $50 \%$ species of class Nardo-Callunetea in corresponding degrees of scales

\begin{tabular}{|l|c|c|c|}
\hline \multirow{2}{*}{$\begin{array}{c}\text { Cechy środowiska geograficznego } \\
\text { Features of the geographical environment }\end{array}$} & \multicolumn{3}{c|}{$\begin{array}{c}\text { Porównywane pary skal } \\
\text { Compared pairs of scales }\end{array}$} \\
\cline { 2 - 4 } & $\mathrm{E}+\mathrm{L}$ & $\mathrm{E}+\mathrm{Z}$ & $\mathrm{L}+\mathrm{Z}$ \\
\cline { 2 - 4 } & \multicolumn{2}{c|}{$\%$ gatunków / Species (\%) } \\
\hline L Światło / Light & 39,2 & 50,0 & 54,7 \\
T Temperatura / Temperature & 57,1 & 57,1 & 36,0 \\
K Stopień kontynentalizmu / Continentality & 34,7 & 20,4 & 54,7 \\
F Wilgotność gleb / Soil moisture & 52,2 & 67,4 & 50,9 \\
R Kwasowość gleb / Soil acidity & 51,1 & 27,3 & 7,9 \\
N Zawartość azotu w glebie / Soil nitrogen & 71,7 & 20,8 & 26,4 \\
\hline
\end{tabular}

gdzie: $\mathrm{E}+\mathrm{L}$ - skale Ellenberga i Landolta, $\mathrm{E}+\mathrm{Z}$ - skale Ellenberga i Zarzyckiego, $\mathrm{L}+\mathrm{Z}$ - skale Landolta i Zarzyckiego

$E+L$ - the Ellenberg and Landolt scales, $E+Z$ - the Ellenberg and Zarzycki scales, $L+Z$ - the Landolt and Zarzycki scales

Wartości wytłuszczone oznaczają zgodność systemów/Bold values indicate similarities of scales

\section{Interpretacja wyników zgodności i różnic porównywanych skal na podstawie zbioru gatunków charakterystycznych wrzosowisk i ubogich muraw bliźniczkowych z klasy Nardo-Callunetea}

Uzyskane wyniki zgodności i różnic porównywanych skal nie pozwalają na jednoznaczne ich wyjaśnienie. Interpretacja może być zatem przeprowadzona na podstawie dwóch przeciwstawnych hipotez (ryc. 3 i 4). Pierwsza zakłada, że porównywane skale są zbliżone gdyż, poszczególnym stopniom odpowiadają te same zakresy rzeczywistych pomiarów, a różnice dotyczą oceny wymagań gatunków jako wskaźników warunków środowiskowych (ryc. 3).

Alternatywna hipoteza dopuszcza, że skale są różne (przesunięte najczęściej o 1 stopień, ale także więcej), a wymagania gatunków względem analizowanych cech środowiska geograficznego są zbliżone (ryc. 4).

Na rycinach 3 (I) i 4 (I) zilustrowano rozkłady liczby gatunków w porównywanych parach skal, natomiast na rycinach 3 (II) i 4 (II) pokazano przesunięcia porównywanych par (różnice w liczbie gatunków w przedziałach wartości różnic między porównywanymi parami). Brak rzeczywistych pomiarów, które pozwoliłyby na bardziej jednoznaczne wyjaśnienie uzyskanych wyników, narzucił konieczność szukania rozwiązań pośrednich.

Analiza histogramów liczby poszczególnych kategorii gatunków pokazuje, że jednoznacznymi przykładami pierwszej koncepcji są: 

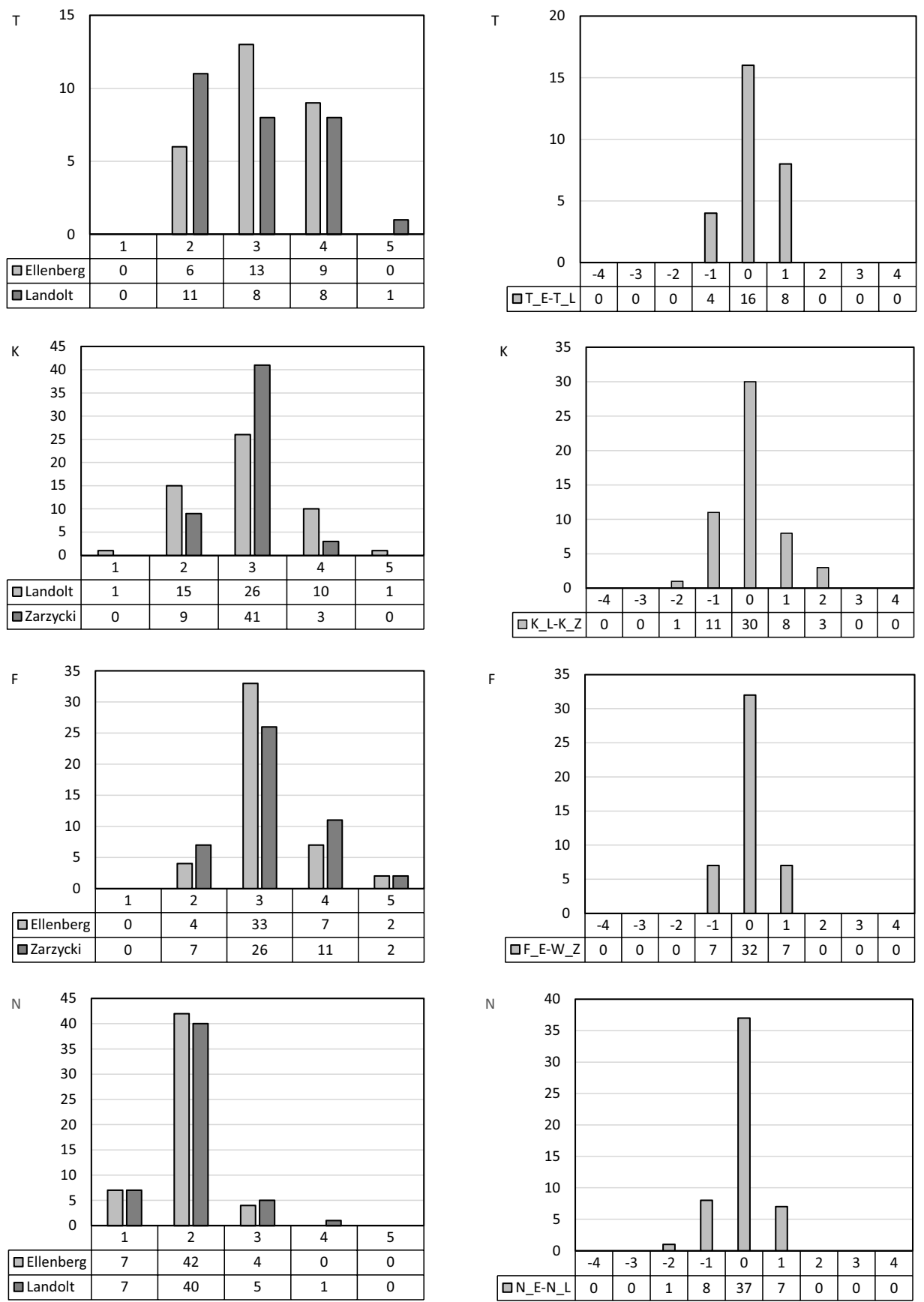
- skale temperatury T-Ellenberga i Landolta (ryc. 3T),

- skale stopnia kontynentalizmu K - Landolta i Zarzyckiego (ryc. 3K),

- skale wilgotności gleb F - Ellenberga i Zarzyckiego (ryc. 3F),

- skale zawartości azotu w glebie N - Ellenberga i Landolta (ryc. 3N).

Według drugiej koncepcji rozkład liczby kategorii gatunków na histogramach pozwala jednoznacznie wyjaśnić różnice (przesunięcia) następujących porównywanych par skal:

- temperatury T - Landolta i Zarzyckiego (ryc. 4L),

- wilgotności F - Landolta i Zarzyckiego (ryc. 4F),

- kwasowości gleb R - Landolta i Zarzyckiego (ryc. 4R),

- zawartości azotu w glebie N - Ellenberga i Zarzyckiego (ryc. 4N).

Warto odnotować, że skala Zarzyckiego odbiega od skal Ellenberga i Landolta i odmiennie diagnozuje wymagania gatunków charakterystycznych wrzosowisk i ubogich muraw bliźniczkowych względem kwasowości siedlisk (liczba R). Landolt i Ellenberg większości gatunkom przypisuje walor wskaźnikowy gleb kwaśnych (R 2 - ok. 50\%), a Zarzycki ok. 50\% gatunków ocenia jako wskaźniki gleb umiarkowanie kwaśnych (R 4) (por. tab. 8). Te różnice mogą wynikać z większego zakwaszenia gleb Szwajcarii niż Polski i Niemiec. Zdaniem holenderskich autorów A. Schaffersa i K. Sykory (2000) liczby kwasowości R lepiej odpowiadają całkowitej zawartości wapnia niż mierzonemu odczynowi gleby $(\mathrm{pH})$. Prawdopodobnie z tego powodu aż 13 gatunków (ok. 25\% całego zbioru) różni się liczbą $\mathrm{R}$ (nawet o dwa stopnie) (patrz tab. 10). Może to też wynikać ze znacznej labilności odczynu gleby, który zmienia się zależnie od warunków pogodowych w krótkich okresach czasu i ma znaczenie wybitnie lokalne (Kozłowska, 1991; Roo-Zielińska, 2014).

Ryc. 3. Histogramy frekwencji gatunków w przedziałach zmienności porównywanych par skal według koncepcji I

Histograms of species attendance between the classes according to concept I $\mathrm{T}$ - skale temperatury Ellenberga i Landolta (T_E - T_L) / the Ellenberg and Landolt scales of temperature ( $T_{-} E-T_{-} L$ )

K - skale stopnia kontynentalizmu Landolta i Zarzyckiego (K_L - K_Z) / the Landolt and Zarzycki scales of continentality ( $K \_L-K \_Z$ )

F-skale wilgotności gleb Ellenberga i Zarzyckiego (F_E - W_Z) / the Ellenberg and Zarzycki scales of soil moisture (F_E - W_Z)

$\mathrm{N}$ - skale zawartości azotu w glebie Ellenberga i Landolta (N_E - N_L) / the Ellenberg and Landolt scales of nitrogen content in soil ( $\left.N_{-} E-N_{-} L\right)$

Wyjaśnienie I / Explanation I (like täble 4)

Oś X - przedziały porównywanych skal / X axis - classes of compared scales

Oś Y - liczba gatunków w przedziałach porównywanych par skal / Y axis - numbers of species in the classes of the compared scale pairs

Wyjaśnienie II / Explanation II (like table 4)

Oś X - przedziały wartości różnic między porównywanymi parami skal / X axis - differences between classes in the compared pair of scales

Oś Y - liczba gatunków w przedziałach wartości różnic między porównywanymi parami skal / Y axis - number of species as regards the difference in value between pairs of scales 
I
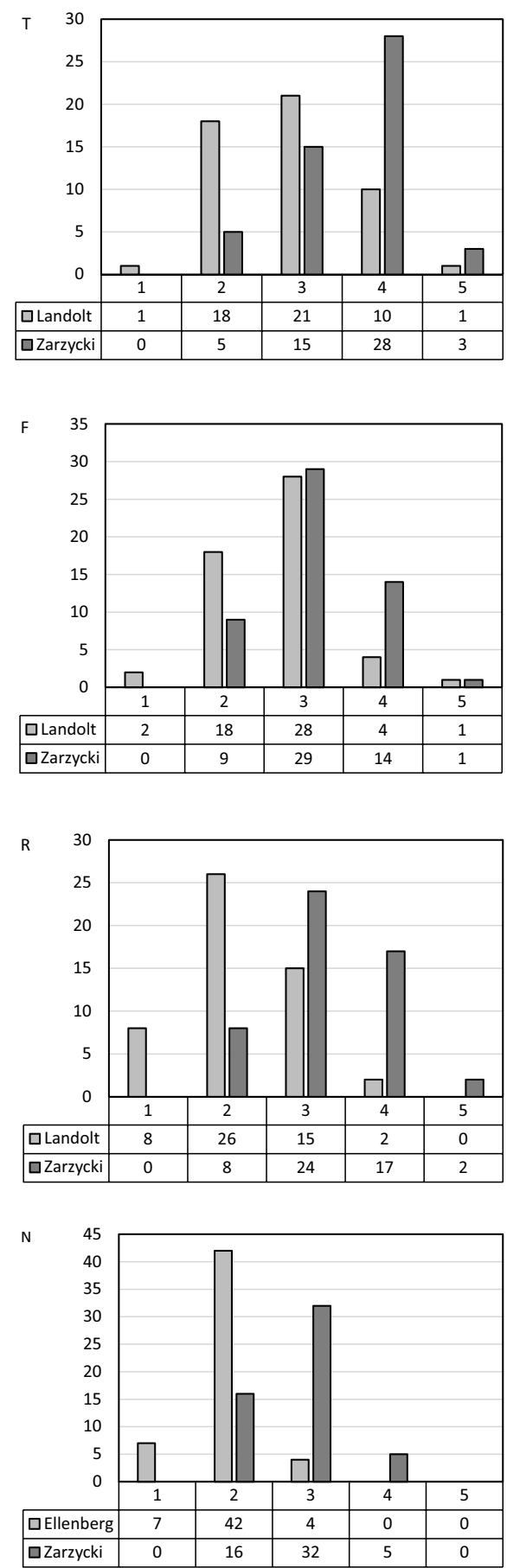

II
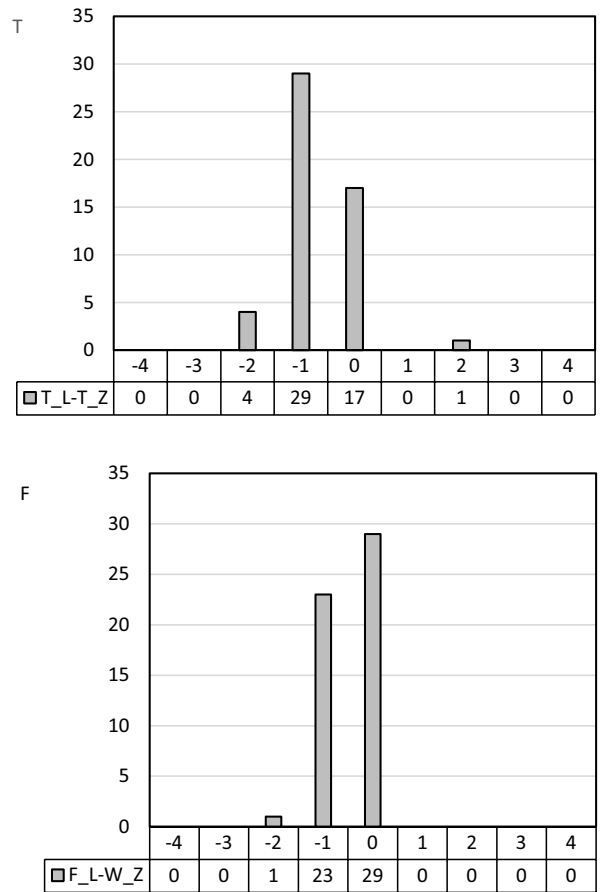

R

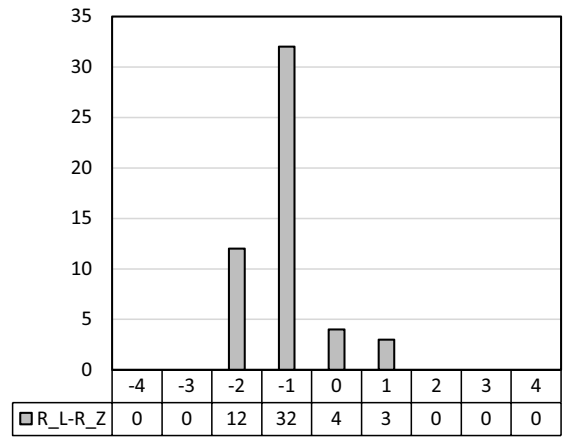

N

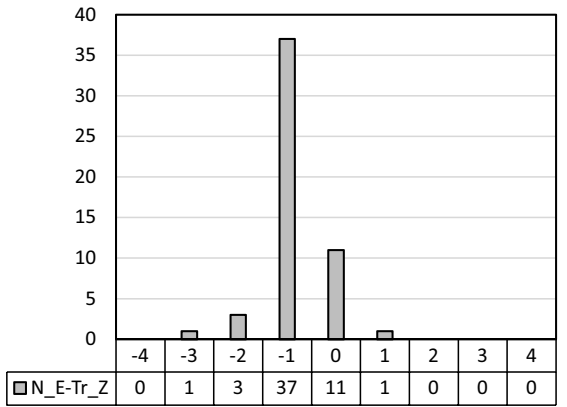


Według skal Ellenberga i Landolta większość gatunków tych zbiorowisk to wskaźniki gleb ubogich w związki azotowe (N 2 - ponad 70\%), natomiast według skali Zarzyckiego znaczącą grupę (ok. 60\%) tworzą indykatory siedlisk umiarkowanie zasobnych (N 3) (tab. 9). Chociaż odniesienie geograficzne skal może mieć wpływ na tę ocenę, to dość istotna wydaje się interpretacja liczby azotu N. Według Ellenberga jest to liczba azotowa N (nitrogen figure) i poprzez nią oceniana jest zawartość w glebie przyswajalnych dla roślin związków azotowych; według Landolta jest to koncentracja składników pokarmowych, tzw. żyzność (nutrient value), według Zarzyckiego natomiast jest to liczba trofizmu $\operatorname{Tr}$ (trophy value).

Wyniki doświadczeń wielu autorów zajmujących się metodami fitoindykacyjnymi i rolą gatunków roślin jako indykatorów zasobności gleb wskazują, że całkowita zawartość mineralnych związków azotowych $\left(\mathrm{NO}_{3}{ }^{-} \mathrm{i} \mathrm{NH}_{4}^{+}\right)$jest w wielu przypadkach słabo indykowana przez gatunki roślin o określonej liczbie N (Hill i Carey, 1997; Schaffers i Sykora, 2000; Diekmann, 2003). Inne składniki odżywcze, a przede wszystkim fosfor i potas są równie dobrze, a czasem lepiej indykowane. A. Schaffers i K. Sykora (2000) wykazali silną korelacją liczby azotowej Ellenberga N z produkcją biomasy i proponują, aby liczbę N zastąpić „liczbą produktywności” (productivity values). Trudności w interpretacji „liczby azotowej N” w pewnym tylko stopniu wyjaśniają różnice w wycechowaniu gatunków jako wskaźników zawartości azotu (żyzności, trofizmu) (Roo-Zielińska, 2014).

Ryc. 4. Histogramy frekwencji gatunków w przedziałach zmienności porównywanych par skal według koncepcji II

Histograms of species attendance between the classes according to concept II

$T$ - skale temperatury Landolta i Zarzyckiego ( $L_{-} L-L_{-} Z$ ) / the Landolt and Zarzycki scales of temperature ( $T_{-} L-T_{-} Z$ )

F-skale wilgotności gleb Landolta i Zarzyckiego (F_E - W_L) / the Landolt and Zarzycki scales of soil moisture (F_L $-W_{-} Z$ )

$\mathrm{R}$ - skale kwasowości gleb Landolta i Zarzyckiego (R_L - R_Z) / the Landolt and Zarzycki scales of soil acidity $\left(R \_L-R \_Z\right)$

$\mathrm{N}$ - skale zawartości azotu w glebie Ellenberga i Zarzyckiego (N_E - Tr_Z) / the Ellenberg and Zarzycki scales of nitrogen content in the soil (N_E - Tr_Z)

Wyjaśnienie I / Explanation I

Oś X - przedziały (stopnie) porównywanych skal / X axis - classes of compared scales

Oś Y - liczba gatunków w przedziałach porównywanych par skal / Y axis - numbers of species in the classes of the compared scale pairs

Wyjaśnienie II / Explanation II

Oś X - przedziały wartości różnic między porównywanymi parami skal / X axis - differences between classes in the compared pair of scales

Oś Y - liczba gatunków w przedziałach wartości różnic między porównywanymi parami skal / Y axis - number of species as regards the difference in value between pairs of scales 


\section{Porównanie różnic i zgodności trzech skal w diagnozie zbiorów gatunków charakterystycznych reprezentujących zbiorowiska należące do pięciu klas fitosocjologicznych}

Podobna analiza porównawcza trzech autorskich skal ekologicznych na podstawie zbioru gatunków wrzosowisk i ubogich muraw bliźniczkowych z klasy Nardo- Callunetea została już przeprowadzona dla muraw napiaskowych z klasy Koelerio glaucae-Corynephoretea (Roo-Zielińska, 2015), muraw ciepłolubnych z klasy Festuco-Brometea (Roo-Zielińska, 2012), łąk z klasy Molinio-Arrhenatheretea (Roo-Zielińska, 2004) oraz lasów liściastych z klasy Querco-Fagetea (Roo-Zielińska, 2009). Łącznie analizie poddano około 460 gatunków roślin naczyniowych, czyli około 23\% liczby taksonów flory polskiej znajdujących się na liście K. Zarzyckiego i innych (2002). Liczba gatunków wahała się w zależności od wskaźnika i porównywanej pary skal (dla wrzosowisk i ubogich muraw bliźniczkowych - ok. 50, dla muraw napiaskowych - ok. 60, dla muraw ciepłolubnych ok. 105, dla łąk - ok. 140 a dla lasów liściastych - ok. 100).

Jak wspomniano klasa Nardo-Callunetea obejmuje acydofilne niskie murawy i łąki z panującą bliźniczką psią trawką oraz zbiorowiska krzewinkowe z panującym wrzosem występujące na ubogich kwaśnych glebach o zmiennej wilgotności. Trzy następne klasy Koelerio glaucae-Corynephoretea, Festuco-Brometea oraz Molinio-Arrhenatheretea reprezentują zbiorowiska trawiaste występujące na podłożu mineralnym. Kolejna - Querco-Fagetea to mezo- i eutroficzne lasy liściaste porastające także gleby mineralne. Murawy napiaskowe i ciepłolubne o wąskiej amplitudzie ekologicznej są podobne w wymaganiach gatunków względem trzech czynników siedliskowych tj. intensywności naświetlenia, wilgotności gleb i zawartości w nich azotu (Roo-Zielińska, 2014). Łąki i lasy liściaste są zróżnicowane wewnętrznie, zwłaszcza pod względem wilgotnościowo-żyznościowym. Pozwala to na sformułowanie prawidłowości wynikających ze zgodności i różnic ekologicznych skal europejskich na podstawie pięciu analizowanych zbiorów gatunków charakterystycznych (tab. 12 i 13).

Skale Ellenberga i Zarzyckiego w zbliżony sposób diagnozują pięć zbiorów gatunków charakterystycznych dotyczących ich wymagań względem intensywności naświetlenia stanowisk określanych liczbą L (tab. 12). Ze względu na specyfikę zbiorów - murawy napiaskowe i ciepłolubne wymienieni autorzy diagnozują jako wskaźniki stanowisk pełnego światła (L 5), ubogich muraw bliźniczkowych i łąk umiarkowanego światła (L 4), a lasów liściastych - umiarkowanego cienia (L 3). Przy czym warto podkreślić, że trzy porównywane skale są zgodne co do waloru wskaźnikowego łąk (tab. 12 i 13).

W przypadku oceny warunków termicznych wyrażonych liczbą T, zgodności skal Ellenberga i Zarzyckiego dotyczą dwóch typów zbiorowisk trawiastych muraw napiaskowych i łąk, a skal Ellenberga i Landolta - muraw ciepłolubnych (tab. 12). Według trzech skal autorskich wszystkie wymienione zbiory gatunków są wskaźnikami obszarów umiarkowanie ciepłych (T 4) (tab. 13). 
Tabela 12. Zgodności porównywanych systemów ekologicznych liczb wskaźnikowych na podstawie ponad 50\% udziału gatunków charakterystycznych należących do pięciu klas fitosocjologicznych w odpowiadających sobie przedziałach zmienności skal

Similarities of compared ecological scales of indicator values based on the share of above-50\% species characteristic for four phytosociological classes in corresponding degrees of scales

\begin{tabular}{|c|c|c|c|c|c|c|c|c|c|c|}
\hline \multirow{3}{*}{$\begin{array}{l}\qquad \text { Klasa / Class } \\
\text { Wrzosowiska i murawy bliźniczkowe } \\
\text { (Nardo-Callunetea) } \\
\text { Heaths and poor grasslands }\end{array}$} & \multicolumn{10}{|c|}{ Liczby wskaźnikowe / Indicator figures } \\
\hline & \multicolumn{3}{|c|}{ L } & \multirow{2}{*}{$\begin{array}{l}\mathrm{T} \\
\\
\bullet\end{array}$} & \multirow{2}{*}{$\begin{array}{l}\mathrm{K} \\
\bullet\end{array}$} & \multicolumn{3}{|c|}{$F$} & \multirow{2}{*}{$\begin{array}{l}\mathrm{R} \\
\bullet \\
\bullet\end{array}$} & \multirow{2}{*}{\begin{tabular}{|c}
$N$ \\
$E+L$
\end{tabular}} \\
\hline & $E+Z$ & $\bullet$ & $L+Z$ & & & $E+Z$ & $E+L$ & $L+Z$ & & \\
\hline $\begin{array}{l}\text { Murawy napiaskowe } \\
\text { (Koelerio glaucae-Corynephoretea) } \\
\text { Sandy grasslands }\end{array}$ & $E+Z$ & $\bullet$ & - & $E+Z$ & $\bullet$ & $E+Z$ & - & - & $\bullet$ & $E+L$ \\
\hline $\begin{array}{l}\text { Murawy ciepłolubne (Festuco-Brometea) } \\
\text { Xerothermic grasslands }\end{array}$ & $E+Z$ & $\bullet$ & - & $E+L$ & - & $E+Z$ & $\bullet$ & $\bullet$ & $E+Z$ & $E+L$ \\
\hline $\begin{array}{l}\text { Łąki (Molinio-Arrhenatheretea) } \\
\text { Meadows }\end{array}$ & $E+Z$ & $E+L$ & $L+Z$ & $E+Z$ & $L+Z$ & $\bullet$ & $\bullet$ & $\bullet$ & $E+Z$ & $\bullet$ \\
\hline $\begin{array}{l}\text { Lasy liściaste (Querco-Fagetea) } \\
\text { Deciduous forests }\end{array}$ & $E+Z$ & $\bullet$ & $\bullet$ & $\bullet$ & $\bullet$ & $E+Z$ & $E+L$ & $L+Z$ & $E+Z$ & $\bullet$ \\
\hline
\end{tabular}

gdzie:

$\mathrm{E}+\mathrm{Z}$ - zgodność systemów Ellenberga i Zarzyckiego / similarity of the Ellenberg and Zarzycki scales

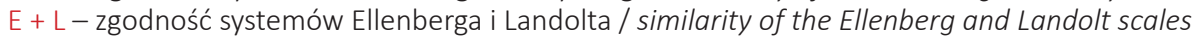
$L+Z$ - zgodność systemów Landolta i Zarzyckiego / similarity of the Landolt and Zarzycki scales

- - brak 50\% zgodności / lack of 50 percent similarities

W przypadku oceny stopnia kontynentalizmu wyrażonym liczbą K tylko skale Landolta i Zarzyckiego wykazały zgodność waloru wskaźnikowego względem tej cechy i dotyczącą tylko zbiorowisk łąkowych (tab. 12). Dwaj autorzy określili w nich znaczący udział gatunków typowych dla przejściowego charakteru klimatu (K 3) (tab. 13).

Ocena wilgotności siedlisk wyrażona liczbą F wskazuje, że spośród pięciu analizowanych zbiorów gatunków charakterystycznych, aż cztery (z wyjątkiem łąk) skale autorskie Ellenberga i Zarzyckiego diagnozują zgodnie walor wskaźnikowy (tab. 12). Murawy napiaskowe i ciepłolubne określają oni jako indykatory gleb suchych (F 2), a wrzosowiska i murawy bliźniczkowe oraz lasy liściaste - jako gleb świeżych (F 3). Warto podkreślić, że Landolt ostatnie dwa zbiory określa także jako wskaźniki gleb świeżych (F 3) (tab. 13).

Ocena kwasowości siedlisk wyrażona liczbą R wskazuje, że dla trzech zbiorów (poza wrzosowiskami i murawami bliźniczkowmi oraz murawami napiaskowymi) zgodności dotyczą dwóch skal Ellenberga i Zarzyckiego (tab. 12). Większość charakterystycznych gatunków łąk i lasów liściastych to wskaźniki gleb słabo kwaśnych i słabo zasadowych (R4), a gatunki muraw ciepłolubnych to indykatory gleb zasadowych (R5) (tab. 13).

Ocena zawartości azotu w glebach wyrażona liczbą N wskazuje, że zgodności dotyczą dwóch skal Ellenberga i Landolta na podstawie waloru wskaźnikowego 
Tabela 13. Ponad 50\% udział gatunków charakterystycznych należących do pięciu klas fitosocjologicznych w przedziałach zmienności porównywanych skal The share of above -50\% species characteristic for five phytosociological classes in degrees of compared scales

\begin{tabular}{|c|c|c|c|c|c|c|c|c|c|c|c|c|c|c|c|}
\hline \multirow[t]{3}{*}{ Klasa / Class } & \multicolumn{5}{|c|}{ Ellenberg } & \multicolumn{5}{|c|}{ Landolt } & \multicolumn{5}{|c|}{ Zarzycki } \\
\hline & \multicolumn{15}{|c|}{ L światło / Light } \\
\hline & 1 & 2 & 3 & 4 & 5 & 1 & 2 & 3 & 4 & 5 & 1 & 2 & 3 & 4 & 5 \\
\hline \multicolumn{16}{|c|}{ Wrzosowiska i murawy bliźniczkowe (Nardo-Callunetea)/Heaths and poor grasslands } \\
\hline \multicolumn{16}{|c|}{ Murawy napiaskowe (Koelerio glaucae-Corynephoretea)/Sandy grasslands } \\
\hline \multicolumn{16}{|c|}{ Murawy ciepłolubne (Festuco-Brometea)/Xerothermic grasslands } \\
\hline \multicolumn{16}{|l|}{ Łąki (Molinio-Arrhenatheretea)/Meadows } \\
\hline \multicolumn{16}{|l|}{ Lasy liściaste (Querco-Fagetea)/Deciduous forests } \\
\hline & \multicolumn{15}{|c|}{ T temperatura / Temperature } \\
\hline & 1 & 2 & 3 & 4 & 5 & 1 & 2 & 3 & 4 & 5 & 1 & 2 & 3 & 4 & 5 \\
\hline \multicolumn{16}{|c|}{ Wrzosowiska i murawy bliźniczkowe (Nardo-Callunetea)/Heaths and poor grasslands } \\
\hline \multicolumn{16}{|c|}{ Murawy napiaskowe (Koelerio glaucae-Corynephoretea)/Sandy grasslands } \\
\hline \multicolumn{16}{|c|}{ Murawy ciepłolubne (Festuco-Brometea)/Xerothermic grasslands } \\
\hline \multicolumn{16}{|l|}{ Łąki (Molinio-Arrhenatheretea)/Meadows } \\
\hline \multicolumn{16}{|l|}{ Lasy liściaste (Querco-Fagetea)/Deciduous forests } \\
\hline & \multicolumn{15}{|c|}{ K stopień kontynentalizmu / Continentality } \\
\hline & 1 & 2 & 3 & 4 & 5 & 1 & 2 & 3 & 4 & 5 & 1 & 2 & 3 & 4 & 5 \\
\hline \multicolumn{16}{|c|}{ Wrzosowiska i murawy bliźniczkowe (Nardo-Callunetea)/Heaths and poor grasslands } \\
\hline \multicolumn{15}{|c|}{ Murawy napiaskowe (Koelerio glaucae-Corynephoretea)/Sandy grasslands } & \\
\hline \multicolumn{16}{|c|}{ Murawy ciepłolubne (Festuco-Brometea)/Xerothermic grasslands } \\
\hline \multicolumn{15}{|l|}{ Łąki (Molinio-Arrhenatheretea)/Meadows } & \\
\hline Lasy liściaste (Querco-Fagetea)/Deciduous forests & & & & & & & & & & & & & & & \\
\hline
\end{tabular}




\begin{tabular}{|c|c|c|c|c|c|c|c|c|c|c|c|c|c|c|c|}
\hline \multirow[t]{3}{*}{ Klasa / Class } & \multicolumn{5}{|c|}{ Ellenberg } & \multicolumn{5}{|c|}{ Landolt } & \multicolumn{5}{|c|}{ Zarzycki } \\
\hline & \multicolumn{15}{|c|}{ F wilgotność gleby / Soil moisture } \\
\hline & 1 & 2 & 3 & 4 & 5 & 1 & 2 & 3 & 4 & 5 & 1 & 2 & 3 & 4 & 5 \\
\hline \multicolumn{16}{|c|}{ Wrzosowiska i murawy bliźniczkowe (Nardo-Callunetea)/Heaths and poor grasslands } \\
\hline \multicolumn{16}{|c|}{ Murawy napiaskowe (Koelerio glaucae-Corynephoretea)/Sandy grasslands } \\
\hline \multicolumn{16}{|c|}{ Murawy ciepłolubne (Festuco-Brometea)/Xerothermic grasslands } \\
\hline \multicolumn{16}{|l|}{ Łąki (Molinio-Arrhenatheretea)/Meadows } \\
\hline \multicolumn{16}{|l|}{ Lasy liściaste (Querco-Fagetea)/Deciduous forests } \\
\hline & \multicolumn{15}{|c|}{ R kwasowość gleby / Soil acidity } \\
\hline & 1 & 2 & 3 & 4 & 5 & 1 & 2 & 3 & 4 & 5 & 1 & 2 & 3 & 4 & 5 \\
\hline \multicolumn{16}{|c|}{ Wrzosowiska i murawy bliźniczkowe (Nardo-Callunetea)/Heaths and poor grasslands } \\
\hline \multicolumn{16}{|c|}{ Murawy napiaskowe (Koelerio glaucae-Corynephoretea)/Sandy grasslands } \\
\hline \multicolumn{16}{|c|}{ Murawy ciepłolubne (Festuco-Brometea)/Xerothermic grasslands } \\
\hline \multicolumn{16}{|l|}{ Łąki (Molinio-Arrhenatheretea)/Meadows } \\
\hline \multicolumn{16}{|l|}{ Lasy liściaste (Querco-Fagetea)/Deciduous forests } \\
\hline & \multicolumn{15}{|c|}{ N zawartość azotu w glebie / Soil nitrogen content } \\
\hline & 1 & 2 & 3 & 4 & 5 & 1 & 2 & 3 & 4 & 5 & 1 & 2 & 3 & 4 & 5 \\
\hline \multicolumn{16}{|c|}{ Wrzosowiska i murawy bliźniczkowe (Nardo-Callunetea)/Heaths and poor grasslands } \\
\hline \multicolumn{16}{|c|}{ Murawy napiaskowe (Koelerio glaucae-Corynephoretea)/Sandy grasslands } \\
\hline \multicolumn{16}{|c|}{ Murawy ciepłolubne (Festuco-Brometea)/Xerothermic grasslands } \\
\hline \multicolumn{16}{|l|}{ Łąki (Molinio-Arrhenatheretea)/Meadows } \\
\hline Lasy liściaste (Querco-Fagetea)/Deciduous forests & & & & & & & & & & & & & & & \\
\hline
\end{tabular}


trzech zborów: wrzosowisk i ubogich muraw bliźniczkowych, muraw napiaskowych i muraw ciepłolubnych (tab. 12). Dwaj autorzy diagnozują większość tych gatunków jako indykatory gleb ubogich w mineralne związki azotowe (N 2) (tab. 13).

Podkreślić należy, że spośród rozpatrywanych zbiorów gatunków charakterystycznych należących do pięciu klas fitosocjologicznych, łąki (kl. Molinio-Arrhenatheretea) charakteryzują się szerokim spektrum wilgotnościowo-żyznościowym.

W skład tej klasy wchodzą bowiem zbiorowiska porastające zarówno gleby suche i mało zasobne w związki azotowe, jak i gleby świeże o umiarkowanej zasobności oraz występujące na siedliskach wilgotnych i bogatych w związki azotowe (Matuszkiewicz, 2001; Roo-Zielińska, 2014). To spowodowało, że w przypadku skali F i N (zwłaszcza Ellenberga i Landolta) nie zanotowano jednej dominującej grupy wskaźników w zbiorowiskach łąkowych (tab. 13).

\section{Podsumowanie}

Na podstawie stosunkowo niewielkiej próby (około 23\% flory roślin naczyniowych Polski) można przeprowadzić krytyczną analizę liczb wskaźnikowych, opracowanych przez trzech autorów dla Europy środkowej, w celu zastosowania ich do oceny siedlisk w warunkach klimatyczno-edaficznych Polski. Na przykład liczba kontynentalizmu (K) Ellenberga oceniająca większość analizowanych charakterystycznych gatunków roślin jako suboceaniczne (K 2), nie odpowiada przejściowym warunkom klimatycznym Polski. Właściwa jest tu liczba K według ekologicznej skali Zarzyckiego, która zdecydowanej większości analizowanych gatunków (nawet należących do ekstrazonalnych muraw ciepłolubnych) nadaje walor wskaźników obszarów o klimacie przejściowym - między suboceanicznym i subkontynentalnym (K 3). Warto również podkreślić, że według szwajcarskiej skali Landolta istnieje w większości przypadków różnica jednego stopnia w diagnozie wymagań gatunków względem warunków glebowych. Dotyczy to liczby F wskazującej na gleby suchsze, liczby R wskazującej na gleby bardziej kwaśne i liczby N wskazującej na gleby mniej zasobne w mineralne związki azotowe, w porównaniu z pozostałymi skalami, a zwłaszcza ze skalą polską.

Uzyskane wyniki i interpretacja zgodności i różnic w diagnozach ekologiczno-siedliskowych trzech popularnych w środkowej Europie ekologicznych skal liczb wskaźnikowych na podstawie pięciu różnorodnych zbiorów gatunków charakterystycznych pozwoliła wskazać na pewne powtarzające się wyżej opisane prawidłowości. Wynikać one mogą: (1) z położenia geograficznego krajów, z których wywodzą się porównywane skale określające diagnozy ekologiczne gatunków jako indykatorów światła i temperatury, (2) różnic regionalnych i lokalnych determinujących diagnozy gatunków jako wskaźników warunków siedliskowych takich jak wilgotność, kwasowość i azot, (3) z zestawu gatunków charakterystycznych właściwych dla flory polskiej jako podstawy analizy. 
Te powtarzające się prawidłowości powinny być potwierdzone na większym zbiorze danych. Jest to możliwe ponieważ w opracowaniu E. Roo-Zielińskiej (2014) poddano analizie fitoindykacyjnej ok. 1600 gatunków roślin naczyniowych charakterystycznych dla 21 klas fitosocjologicznych, reprezentujących większość zbiorowisk roślinnych Polski niżowej. Zaznaczyć należy, że szacunkową ocenę wybranych warunków środowiska przyrodniczego przeprowadzono tylko na podstawie jednej, najczęściej stosowanej w Europie, skali ekologicznych liczb wskaźnikowych Ellenberga (Ellenberg i inni 1991; Lindacher, 1995). Jest to więc doskonały materiał do prowadzenia dalszych badań porównawczych trzech autorskich skal ekologicznych, które pozwoliłyby: (1) określić wiarygodność gatunków charakterystycznych zbiorowisk roślinnych jako „wzorcowych, modelowych” wskaźników warunków środowiska fizycznogeograficznego oraz (2) przyjąć skalę ekologicznych liczb wskaźnikowych najbardziej odpowiednią dla zbiorowisk roślinnych Polski.

\section{Piśmiennictwo}

Diekmann M., 2003, Species indicator values as an important tool in applied plant ecology - a review, Basic and Applied Ecology, 4, s. 1-14.

Dzwonko Z., Loster S., 2000, Testing of Ellenberg and Zarzycki indicator values as predictors of soil and light conditions in woodlands, [w:] J.J. Wójcicki, J. Wołek, U. Korzeniak (red.), Fragmenta Floristica et Geobotanica, 45, 1-2, s. 49-62.

Ellenberg H., Weber H.E., Düll R., Wirth V., Werner W., Paulissen D., 1991, Zeigerwerte von Pflanzen in Mitteleuropa, Scripta Geobotanica, 18, s. 1-248.

Falińska K., 1997, Ekologia roślin. Podstawy teoretyczne, populacja, zbiorowisko, procesy, Wydawnictwo Naukowe PWN, Warszawa.

Hill M.O., Carey P.D., 1997, Prediction of yield in the Rothamsted Park grass experiment by Ellenberg indicator values, Journal of Vegetation Science, 8, s. 579-586.

Kershaw K. A., 1978, Ilościowa i dynamiczna ekologia roślin, PWN, Warszawa.

Kostrowicki A., Wójcik Z., 1972, Podstawy teoretyczne i metodyczne oceny warunków przyrodniczych, [w:] Metody oceny warunków przyrodniczych produkcji rolniczej, Biuletyn Komitetu Przestrzennego Zagospodarowania Kraju PAN, 71, Warszawa, s. 7-64.

Kozłowska A., 1991, Analiza porównawcza ekologicznych liczb wskaźnikowych (wg Ellenberga i Zarzyckiego). Comparative analysis of ecological indicative values (according to Ellenberg and Zarzycki), Wiadomości Botaniczne, 35, 1, s. 11-21.

Landolt E., 1977, Ökologische Zeigerwerte zur Schweizer Flora, Veröffentlichungen Geobotanisches Institut der ETH Stiftung Rübel, 64, Zürich.

Lindacher R. (red.), 1995, PHANART Datenbank der Gefässpflanzen Mitteleuropas, Erklarung der Kennzahlen, Aufbau und Inhalt (PHANART Database of Centraleuropean Vascular Plants, Explanation of codes, Structure and Contents), Veröffentlichungen des Geobotanischen Institut der ETH, Stiftung Rübel, 125, Zürich. 
Matuszkiewicz W., 2001, Przewodnik do oznaczania zbiorowisk roślinnych Polski, Wydawnictwo Naukowe PWN, Warszawa.

Motyka J., 1962, Ekologia roślin. Część ogólna i analityczna, Państwowe Wydawnictwo Rolnicze i Leśne, Warszawa.

Podbielkowski Z., 1991, Geografia roślin, Wydawnictwa Szkolne i Pedagogiczne, Warszawa.

Remmert H., 1985, Ekologia, Państwowe Wydawnictwo Rolnicze i Leśne, Warszawa.

Roo-Zielińska E., 2004, Fitoindykacja jako narzędzie oceny środowiska fizycznogeograficznego. Podstawy teoretyczne i analiza porównawcza stosowanych metod, Prace Geograficzne, Instytut Geografii i Przestrzennego Zagospodarowania PAN, 199, Warszawa.

Roo-Zielińska E., 2009, Porównanie europejskich skal ekologicznych liczb wskaźnikowych w ocenie środowiska fizycznogeograficznego na podstawie charakterystycznych gatunków roślin lasów liściastych z klasy Querco-Fagetea, Przegląd Geograficzny, 81, 3, s. 317-345.

Roo-Zielińska E., 2012, Porównanie europejskich skal ekologicznych liczb wskaźnikowych w ocenie środowiska fizycznogeograficznego na podstawie charakterystycznych gatunków roślin muraw ciepłolubnych z klasy Festuco-Brometea, Przegląd Geograficzny, 84, 1, s. 23-51.

Roo-Zielińska E., 2014, Wskaźniki ekologiczne zespołów roślinnych Polski, Wydawnictwo SEDNO, Instytut Geografii i Przestrzennego Zagospodarowania PAN, Warszawa.

Roo-Zielińska E., 2015, Porównanie europejskich skal ekologicznych liczb wskaźnikowych w ocenie środowiska fizycznogeograficznego na podstawie charakterystycznych gatunków roślin muraw napiaskowych z klasy Koelerio glauce-Corynephoretea, Przegląd Geograficzny, 87, 1, s. 409-438.

Roo-Zielińska E., Solon J., Degórski M., 2007, Ocena stanu i przekształceń środowiska przyrodniczego na podstawie wskaźników geobotanicznych, krajobrazowych i glebowych (Podstawy teoretyczne i przykłady zastosowań), Monografie, Instytut Geografii i Przestrzennego Zagospodarowania PAN, 9, Warszawa.

Schaffers A.P., Sykora K.V., 2000, Reliability of Ellenberg indicator values for moisture, nitrogen and soil reaction: a comparison with field measurements, Journal of Vegetation Science, 11, s. 225-244.

Strain B.R., Billings D.W. (red.), 1974, Vegetation and environment, Handbook of Vegetation Science, 6, W. Junk, The Hague.

Wysocki Cz., Sikorski P., 2009, Fitosocjologia stosowana w ochronie i kształtowaniu krajobrazu, Wydawnictwo SGGW, Warszawa.

Zarzycki K., Trzcińska-Tacik H., Różański W., Szeląg Z., Wołek J., Korzeniak U., 2002, Ecological Indicator Values of Vascular Plants of Poland. Ekologiczne liczby wskaźnikowe roślin naczyniowych Polski, W. Szafer Institute of Botany, Polish Academy of Sciences, Kraków. 


\section{Summary}

Comparative analysis was performed in relation to the ecological scales of indicator values for plant species proposed by: (1) Ellenberg for the flora of Germany, (2) Landolt for the flora of Switzerland and (3) Zarzycki for the flora of Poland, in relation to six environmental features, i.e. the climatic features of light intensity $[\mathrm{L}]$, temperature $[\mathrm{T}]$ and continentality $[\mathrm{K}]$, and the edaphic features of moisture $[F]$, acidity $[R]$ and nitrogen content $[N]$. Characteristic species of heaths and poor grasslands from class Nardo-Callunetea were used as the" tool" in the above comparison. Numbers of species involved ranged from 28 to 53, depending on the environmental features and compared scales involved. The assumption was that pairs of ecological scales were similar where the percentage share of species is above $50 \%$ in corresponding numbers along the scales. The main aim of the analysis was in turn to determine if compared scales originating from different parts of central Europe were similar (or distinct) in their ecological (climatic and edaphic) diagnoses, as expressed in terms of three indicator values (corresponding to three scales) for each relevant feature of the geographical environment.

Results obtained were interpreted by reference to two opposing hypotheses. The first assumes that the scales compared are similar, with particular numbers along the scales conforming to the same ranges of actual measurements, while differences concern the assessment of the requirements of the species as indicators of environmental conditions. The second, alternative hypothesis assumes that the scales are different (most often shifted by one degree), while the ecological requirements of the species are similar.

Analysis of histograms for frequencies of particular species categories shows that examples sustaining the first of the two hypotheses are provided by the pairs of scales of: (1) temperature [T] of Ellenberg and Landolt; (2) continentality (K) of Landolt and Zarzycki, (3) soil moisture [F] of Ellenberg and Zarzycki; (4) nitrogen content in the soil [N] of Ellenberg and Landolt.

In relation to the second hypothesis, the distribution of frequencies of the species categories in the histograms allows for the explanation of differences (in terms of shifts) within the following pairs of scales compared: (1) temperature [T] of Landolt and Zarzycki; (2) soil moisture [F] of Landolt and Zarzycki; (3) soil moisture of Landolt and Zarzycki; (4) soil acidity of Landolt and Zarzycki; (5) nitrogen content in the soil [N] of Ellenberg and Zarzycki.

It is worth noting that a similar analysis was achieved when the same ecological scales of indicator values were compared by reference to meadow species from class Molinio-Arrhenathereta (Roo-Zielinska, 2004), deciduous forest of class Querco-Fagetea (Roo-Zielińska, 2009), xerothermic grasslands of class Festuco-Brometea (Roo-Zielińska, 2012) and sandy xeric grasslands of class Koelerio glaucae-Corynephoretea canescentis class (Roo-Zielińska, 2015). This means that a total of some 460 species (of meadows, deciduous forests, xerothermic and 
sandy xeric grasslands, and heaths and poor grasslands) have now been evaluated. While this still only represents some $23 \%$ of K Zarzycki's list of the Polish flora (Zarzycki et al., 2002), very different ecological spectra and tolerance in the five groups have not precluded the highlighting of certain regularities applying to the plant communities already studied. The results obtained point to the need for comparative analysis of European ecological scales for groups of characteristic species belonging to different phytosociological units/associations to be continued with, with ecological indicator values appropriate to Poland's flora and plant communities then being found. 